\title{
Moral hazard, dividends, and risk in banks
}

\author{
Enrico Onali ${ }^{+}$ \\ Bangor Business School
}

\begin{abstract}
In nonfinancial firms, higher risk taking results in lower dividend payout ratios. In banking, public guarantees may result in a positive relation between dividend payout ratios and risk taking. I investigate the interplay between dividend payout ratios and bank risk-taking allowing for the effect of charter values and capital adequacy regulation. I find a positive relation between bank risk-taking and dividend payout ratios. Proximity to the required capital ratio and a high charter value reduce the impact of bank risk-taking on the dividend payout ratio. My results are robust to different proxies for the dividend payout ratio and bank risk-taking.
\end{abstract}

\section{Keywords: Dividend, bank risk taking, moral hazard JEL classification: G21, G35}

\footnotetext{
+ e.onali@bangor.ac.uk. Bangor Business School, Bangor University, LL57 2DG.
}

\begin{abstract}
Acknowledgments.
I wish to thank Andrew Stark (the editor), an anonymous referee, John Goddard, Klaus Schaeck, Bob DeYoung, David Roodman, Clovis Rugemintwari, André Güttler, Balasingham Balachandran, Andrea Sironi, Iftekhar Hasan, Jane Ihrig, Alberto CyboOttone, Philip Molyneux, Jonathan Williams, Owain ap Gwilym, Lynn Hodgkinson, Graham Partington, Tim Zhou, Angelo Zago, Sven Bornemann, Giuseppe Torluccio, Andi Duqi, Brunella Bruno, and participants at the AIDEA Bicentenary Conference, XX Tor Vergata Conference in Money Banking and Finance, the 8th annual meeting of Eurofidai, the 37th annual meeting of the European Finance Association, the 22nd Australasian Finance and Banking Conference, the UKEPAN conference, and seminars at the University of Bologna and at Bangor University. A previous version of the paper was awarded the Young Economist Session prize at the XX Tor Vergata Conference in Money Banking and Finance.
\end{abstract}




\section{Introduction}

The literature on the determinants of dividend payout ratios tends to exclude regulated industries from the analysis. An exception is Hansen et al. (1994), who investigate the relation between dividend payout ratios and monitoring in the utilities industry. In this paper, I take a closer look at the determinants of dividend payout ratios of another important regulated industry: The banking industry.

The new Basel III framework imposes restrictions on dividends for undercapitalised banks (Caruana, 2010), but it is unclear whether previous versions of the framework were effective in curbing risk-shifting. To fill this gap in the literature, I provide an empirical investigation of three important research questions: Are bank risk-taking and dividend payout ratios related? Have minimum capital requirements been successful in preventing banks from using dividends as a risk-shifting device? Is a high charter value (also franchise value) a deterrent for riskshifting via high dividend payout ratios?

These questions are crucial for policy makers that aim to mitigate the impact of moral hazard on bank safety and, due to the importance of bank safety for the real economy, for society as a whole. Moreover, these questions are key to understanding the dynamics of the relation between the dividend payout ratio and risk-taking for industries where regulators and creditors are important stakeholders. Therefore, answering these questions is of interest to banking and corporate finance academics alike, as well as policy makers and regulators.

I investigate the role of high dividend payout ratios as a risk-shifting mechanism that can exacerbate moral hazard deriving from public guarantees, allowing for the effect of capital adequacy requirements and heterogeneity in charter values. In contrast with Acharya et al. (2011), I do not focus specifically on the crisis period. I investigate the relation between dividend payout ratios and bank risk-taking during the years 2000-2007, before the 2008-2009 recession, to limit the influence of extraordinary regulatory measures on my analysis. Focussing 
on the period 2000-2007 also mitigates concerns regarding heterogeneous responses to the implementation of Basel II. ${ }^{1}$

The main hypothesis tested in the paper, henceforth referred to as the risk-shifting hypothesis, posits that risk taking is positively related to dividend payout ratios, since banks can pay dividends to transfer default risk to their creditors and (when bailouts take place) to the taxpayer. For consistency with previous literature on dividend policy of nonfinancial firms, and to avoid excluding unlisted banks from the investigation, I employ dividends to net income as main proxy for the dividend payout ratio. However, robustness tests show that my results hold even when using alternative proxies for the dividend payout ratio: dividends to book value of equity, dividends to market value of equity, and dividends plus share repurchases to market value of equity.

In addition to the risk-shifting hypothesis, this paper investigates two additional hypotheses, relating to the influence of capital adequacy requirements and charter values: According to the opportunity cost hypothesis, undercapitalised banks (banks with a regulatory capital ratio close to the minimum allowed by capital adequacy regulation) should decrease dividend payout ratios to avoid future actions by the regulators. According to the charter value hypothesis, banks with high charter values should be discouraged from paying dividends to preserve the charter.

I test the three hypotheses above on a sample of 741 U.S. and EU banks, and subsequently on a sub-sample of 166 listed banks. Investigating listed banks separately has several advantages. First, for listed banks the signalling content associated with dividends (Bhattacharya, 1979; John and Williams, 1985; Miller and Rock, 1985) may affect bank dividend policy. Agency costs (Easterbrook, 1984; Jensen, 1986) and catering incentives (Baker and Wurgler, 2004) may also play a role, although evidence on the latter is mixed (Hoberg and Prabhala, 2009). ${ }^{2}$ Second,

\footnotetext{
${ }^{1}$ Basel II rules were adopted in the EU as early as 2006, but the new rules of capital adequacy requirements were not fully implemented until 2008. In the U.S., Basel II was only partially adopted, and became effective from April 2008.

${ }^{2}$ Hoberg and Prabhala (2009) suggest that the dividend premium may proxy for risk rather than dividend fads.
} 
for listed banks I can employ forward-looking measures of risk taking that are based on both accounting and market based information. In particular, for the analysis regarding both listed and unlisted banks I employ an accounting measure of distance to default (the log of the Zscore), while for the analysis regarding listed banks only I employ a measure of distance to default that is based on both accounting and market data (Bharath and Shumway's distance to default) and, in robustness tests, the related concept of Expected Default Frequency (EDF). ${ }^{3}$

This paper contributes to the literature in several ways.

First, it provides novel evidence of a positive relation between bank risk-taking and dividend payout ratios in banking, controlling for heterogeneity in the regulatory capital position and charter value of the bank.

Second, it sheds light on the impact of capital adequacy requirements on dividend payout ratios prior to and during the crisis (2008-2009), while recent papers (such as Acharya et al., 2011) focus only on the crisis period. I find that banks that are close to the minimum capital requirement have significantly lower dividends payout ratios than well-capitalised banks. These results are consistent with the view that capital adequacy regulations in force before Basel III were somewhat effective in offsetting the positive relation between dividend payout ratios and bank risk-taking. In this respect, I also provide evidence that Prompt Corrective Actions (PCA) in the U.S. help curb the dividend payout ratio when the bank is close to the regulatory minimum.

Third, banks with higher charter value have lower dividend payout ratios, consistent with the view that when charter value is high, banks have an incentive to preserve the charter (Keeley, 1990).

\footnotetext{
${ }^{3}$ Recent papers employ distance to default measures as a proxy for bank risk-taking (for instance, Hagendorff and Vallascas, 2011)
} 
Finally, recent empirical studies on the determinants of dividend payout ratios in nonfinancial firms (Li and Zhao, 2008; Chay and Suh, 2009) neglect the autoregressive nature of the dividend payout ratio. Since the lagged payout ratio may well be correlated with other determinants of the current dividend payout ratio, this approach can lead to omitted variable bias. I employ a dynamic panel data model to adequately model an autoregressive component in the dividend payout ratio.

My results are robust to the proxy for agency costs between insiders and outsiders (Rozeff, 1982), the legal framework of the country of origin (La Porta et al., 2000; Faccio et al., 2001), and inclusion of the crisis period (2008-2009) in the analysis.

The remainder of the paper is organised as follows. Section 2 reviews the literature and develops the hypotheses. Section 3 describes the methodology and the data set. Section 4 reports the main results and robustness checks. Section 5 provides concluding remarks.

\section{Related Literature and Hypotheses}

This section briefly reviews the literature on dividend policy of nonfinancial firms and banks, and develops the hypotheses.

\subsection{Literature on dividend policy: A brief review}

Dividend policy is a key topic in the financial economics literature. Most of the literature on dividend policy is concerned with the importance of dividend policy for firm value. Miller and Modigliani (1961) introduce the idea of irrelevance of dividend policy for the value of a firm. However, their theory is grounded upon the concept of "perfect" capital markets with rational investors.

Dividend policy may be relevant for firm value because of imperfections in real financial markets. The early literature studies three main real-market imperfections (Lease et al., 2000): 
different tax rates on dividends and capital gains, informational asymmetries between insiders and outsiders, and agency costs. More recently, the literature has also investigated the role of the legal framework of the country of origin (La Porta et al., 2000), catering incentives (Baker and Wurgler, 2004), and the stage of the life-cycle of the firm (DeAngelo et al., 2006). Baker et al. (2002) provide a useful survey of seminal contributions in the dividend policy literature.

Identifying the impact of different determinants of dividend policy unambiguously is a daunting challenge, and the empirical literature has produced mixed results with regard to the impact of tax clienteles, signalling effects, and life-cycle factors (Farrar and Selwyn, 1967; Brennan, 1970; Healy and Palepu, 1988; Grullon et al., 2005; DeAngelo et al., 2006; von Eije and Megginson, 2008; Denis and Osobov, 2008; De Cesari, 2012). Exploiting a unique historical setting, Turner et al. (2013) provide evidence that the information content of dividends is more important than agency, catering, or behavioural determinants of dividend policy.

The banking literature has so far overlooked the topic of dividend policy, with some exceptions regarding primarily the signalling power of dividend cuts and omissions in banks (Keen, 1983; Bessler and Nohel, 1996, 2000). In particular, the study of the determinants of dividend payout ratios in banking is so far an under-researched area. This paper contributes to the literature on the determinants of the dividend payout ratio, and extends the findings of studies on the effect of risk taking on the dividend payout ratio (Rozeff, 1982; Chay and Suh, 2009) to the banking sector.

I borrow from two main strands of literature to develop my hypotheses. The first strand investigates the determinants of the dividend payout ratio of nonfinancial firms. The second strand examines the relation between regulation and bank risk-taking, and illustrates why certain types of regulation produce moral hazard (which, in turn, is related to the literature on market 
discipline). ${ }^{4}$ Section 2.2 examines this latter strand of literature and develops the hypotheses tested in this paper.

\subsection{Hypotheses}

Deposit insurance regulation, and public guarantees in general, may increase the likelihood of moral hazard in the form of excessive risk taking because it discourages monitoring from depositors. Deposit insurance can be thought of as a put option on the bank's assets (Merton, 1977), whose value is positively related to business risk and leverage. Under a fixed-rate system, banks can exploit the deposit insurance by increasing leverage and risk (Keeley, 1990). In the event of default, banks can exploit deposit insurance to obtain wealth from the insuring agency. Accordingly, the value of deposit insurance is positively related to default risk.

Dividends play an important role for the pricing of public guarantees. Dividends decrease the value of assets, which implies a decrease in the value of both equity and debt, but benefit only the owners of the bank - equity is 'dividend protected' (Ronn and Verma, 1986). ${ }^{5}$ Ceteris paribus, higher dividend payout ratios increase default risk and the value of public guarantees (implicit or explicit). Moreover, banks tend to sell their safer assets to distribute dividends, and leave on their balance sheets the riskier assets (Acharya et al., 2011).

In the absence of specific regulations that curb dividend payments in times of distress, bank owners/managers can 'loot' the public by strategically increasing dividend payout ratios, to extract wealth from bank creditors (depositors) and the insuring agency (Akerlof and Romer, 1993).

Based on these considerations, the main hypothesis tested in this paper is as follows.

\footnotetext{
${ }^{4}$ Recent research has investigated whether regulations in the financial sector (particularly deposit insurance and capital adequacy regulation) impinge on the determinants of the financing decisions of banks (Gropp and Heider, 2010). This paper assumes a similar perspective, in that it investigates the dynamics of the relation between dividends and risk under bank regulations.

${ }^{5}$ For an analytical discussion about the pricing of public guarantees and dividends, see Appendix.
} 


\section{$\mathrm{H}_{1}$ : Risk-shifting hypothesis}

Bank risk-taking is positively related to dividend payout ratios.

To restrain moral hazard deriving from public guarantees, bank regulators have introduced capital adequacy requirements proportional to a bank's risky assets. Capital adequacy requirements should counteract moral hazard because they force banks to internalise the adverse consequences of excessive risk taking. Undercapitalised banks can improve their capital position either by means of dividend cuts or by issuing new equity capital. Because raising new equity capital is expensive (Hellmann et al., 2000) and conveys negative information to the financial market (Polonchek et al., 1989), paying dividends implies foregoing the opportunity to raise the required capital (at no additional cost) by retaining earnings. High payout ratios increase the likelihood of dividend cuts in the future, which can result in large drops in bank stock returns (Lintner, 1956; Polonchek et al., 1989; Bessler and Nohel, 1996). Therefore, undercapitalised banks should distribute a smaller percentage of earnings than well-capitalised banks.

\section{$\mathrm{H}_{2}$ : Opportunity cost hypothesis}

Undercapitalised banks have lower dividend payout ratios than well-capitalised banks.

Acharya et al. (2012) introduce a theoretical model that highlights the importance of charter values in the dynamics of the relation between risk-shifting incentives and dividends. In a nutshell, Acharya et al. (2012) argue that banks may pay excessive amounts of dividends because they do not internalize the negative externalities that generous dividend policies may impose on other banks (via the interbank lending channel). The model stresses that risk-shifting is more likely to occur in periods during which charter values are low, consistent with previous literature arguing that when charter values are low, banks have little to lose and the incentive to 
gamble and exploit public guarantees is high (Keeley, 1990). ${ }^{6}$ On the other hand, when charter values are high the incentive to exploit public guarantees is low because liquidation would prevent bank owners from selling the charter (i.e., the charter value would be lost). Therefore, banks with high charter values should be less inclined to engage in risk shifting via dividend payments. These considerations lead to the following testable hypothesis:

\section{$\mathbf{H}_{3}$ : Charter value hypothesis}

Charter value is negatively related to dividend payout ratios.

\section{Methodology and Data}

This section describes the methodology, data collection, and the construction of the sample.

\subsection{Methodology}

I investigate the nexus between dividend payout ratios and bank risk-taking using a dynamic panel data model. Previous research on the determinants of payout ratios in nonfinancial firms employs dividends to net income $(D P)$ as a dependent variable. For comparability with this literature, I employ $D P$ as a proxy for the dividend payout ratio for the sample including all banks. For the sub-sample of listed banks only, I employ the ratio of dividends to market value of equity $(D Y)$ and, in robustness tests, the total payout ratio (dividends plus share repurchases divided by the market value of equity).

$D P$ becomes infinite when earnings are zero, and when earnings are negative there is a negative relation between dividends and the dividend payout ratio. Following Chay and Suh (2009) I drop observations for which $D P$ is negative. ${ }^{7}$ Robustness tests show that the results do not

\footnotetext{
${ }^{6}$ For instance, Keeley (1990) ascribes the U.S. savings and loan crisis of the 1980s to more intense competition between banks (driven by deposit rate deregulation). Fiercer competition caused a decline in the charter value of savings and loan institutions. In such circumstances, these institutions were incentivised to exploit the put option implied by the deposit insurance scheme.

${ }^{7}$ Replacing these observations with a zero does not change substantially my results.
} 
change substantially when using dividends to book value of equity $(D E)$. Using $D E$ eliminates the possibility of negative dividend payout ratios.

The specification of the model is as follows:

$$
\begin{aligned}
& \mathrm{Y}_{\mathrm{it}}=\alpha+\rho \mathrm{Y}_{\mathrm{it}-1}+\boldsymbol{\beta}^{\prime} \mathbf{x}_{\mathrm{it}}+\boldsymbol{\gamma}^{\prime} \mathbf{c}_{\mathrm{it}}+\varepsilon_{\mathrm{it}} \\
& \varepsilon_{\mathrm{it}}=\eta_{\mathrm{i}}+v_{\mathrm{it}} \\
& \mathrm{E}\left[\eta_{\mathrm{i}}\right]=\mathrm{E}\left[v_{\mathrm{it}}\right]=\mathrm{E}\left[\eta_{\mathrm{i}}, v_{\mathrm{it}}\right] \\
& \eta_{\mathrm{i}} \sim \mathrm{N}\left(0, \sigma_{\eta}^{2}\right) \text { and } v_{\mathrm{it}} \sim \mathrm{N}\left(0, \sigma^{2}\right)
\end{aligned}
$$

where $i=1,2, \ldots, N$ indexes observational units (banks); $t=1,2, \ldots, T$ indexes time (years); $\mathrm{Y}_{\mathrm{it}}$ is the proxy for the payout ratio, $D P ; \boldsymbol{\beta}$ and $\boldsymbol{\gamma}$ are vectors of coefficients; $\mathbf{x}_{\mathbf{i t}}$ is a vector of covariates, including the main explanatory variables associated with the three hypotheses; and $\mathbf{c}_{\mathbf{i t}}$ is a vector of controls. The error term $\varepsilon_{\mathrm{it}}$ consists of an unobserved panel-level effect $\eta_{\mathrm{i}}$ (fixed for each bank $i$ ) and an idiosyncratic component $v_{\mathrm{it}}$ (independent and identically distributed over all observations).

Due to the presence of the lagged dependent variable $\mathrm{Y}_{\mathrm{it}-1}$ among the regressors, a dynamic panel data specification is required (Nickell, 1981). The generalised method of moments (GMM) estimator, developed by Arellano and Bond (1991) and refined by Arellano and Bover (1995) and Blundell and Bond (1998), eliminates $\eta_{\mathrm{i}}$ via differencing, and allows for $\mathrm{E}\left(\Delta \mathrm{Y}_{\mathrm{it}-1}\right.$, $\left.\Delta v_{\mathrm{it}}\right) \neq 0$ using the lagged levels of $\mathrm{Y}_{\mathrm{it}-1}$ as instruments $\left(\mathrm{Y}_{\mathrm{it}-2}\right.$ is correlated to $\Delta \mathrm{Y}_{\mathrm{it}-1}$ but uncorrelated to $\Delta v_{\mathrm{it}}$ ). While Arellano and Bond's (1991) estimator (GMM-DIF) employs only lagged levels of $\mathrm{Y}_{\mathrm{it}-1}$ as instruments in the first-differenced equation, Blundell and Bond's (1998) estimator (GMM-SYS), based upon Arellano and Bover (1995), involves a system of first-differenced and level equations, where lags of levels (in the former) and lags of the first differences (in the latter) are employed as instruments. Similar to Khan (2006) and Andres et al. (2009), I prefer the GMM-SYS to GMM-DIF for my analysis. 
As pointed out by Roodman (2009), the GMM-SYS has one main drawback. The use of too many instruments can weaken the Hansen (1982) test of over-identifying restrictions, leading to an undersized test. To address the issue of instrument proliferation, I employ the collapsing technique suggested by Roodman (2009). This technique employs one instrument for each endogenous variable and lag length (instead of one for each time period, endogenous variable, and lag length), considerably reducing the number of instruments.

\subsection{Definition of explanatory variables}

In this section, I briefly define the variables employed to test $\mathrm{H}_{1}-\mathrm{H}_{3}$. I test the risk-shifting hypothesis $\left(\mathrm{H}_{1}\right)$ using several proxies for bank risk-taking: the log of the Z-score (Laeven and Levine, 2009; Schaeck et al., 2012; Beck et al., 2013); a forward-looking measure of distance to default (introduced by Bharath and Shumway, 2008), which I denote as Nä̈ve DD; and the EDF based on Nä̈ve DD. Employing only forward-looking measures based on stock price data would result in sample selection bias, while using these three measures improves the robustness of my results and allows considering both listed and unlisted banks. These three measures are defined in detail in Table 1. According to $\mathrm{H}_{1}$, there should be a negative relation between the log of the Z-score and the dividend payout ratio, between Nä̈ve $D D$ and the dividend payout ratio, and between $\{-E D F\}$ and the dividend payout ratio.

I test the opportunity cost hypothesis $\left(\mathrm{H}_{2}\right)$ by creating a dummy variable (Close) equal to one if either the tier 1 ratio (Tier 1 ) of the previous year is below $6 \%$ or the total regulatory capital ratio $(T C R)$ of the previous year is below $10 \%$, and zero otherwise. The total regulatory capital ratio is total regulatory capital divided by risk-weighted assets under Basel rules. Tier 1 is tier 1 capital divided by risk-weighted assets under Basel rules. According to $\mathrm{H}_{2}$, the coefficient on Close should be negative.

The banking literature suggests that customer (demand) deposits contribute to a bank's charter value (Marcus, 1984; James, 1991; Hutchison and Pennacchi, 1996; Goyal, 2005; Schaeck et al., 
2012). To test $\mathrm{H}_{3}$, I create a dummy variable (High Charter) that takes on the value one if the ratio of customer deposits to total assets is larger than the sample median (charter value is high), and zero otherwise (charter value is low). For $\mathrm{H}_{3}$ to hold, the coefficient of High Charter should be negative. In the tests using listed banks only (and Nä̈ve $D D$ or $E D F$ as a measure of risk taking), I employ the market-to-book ratio as a proxy for charter value (Cebenoyan et al., 1999).

The existing literature about dividend policies in nonfinancial firms finds that the following firm characteristics can influence dividend policy: insider-outsider (IO) conflict (Easterbrook, 1984; Jensen, 1986; Faccio et al., 2001), asset growth (Fama and French, 2001), size (Fama and French, 2001; DeAngelo et al., 2004; Denis and Osobov, 2008), profitability (Fama and French, 2001; DeAngelo et al., 2004; Denis and Osobov, 2008), earned equity (DeAngelo et al., 2006; von Eije and Megginson, 2008; DeAngelo and DeAngelo, 2007), a recent quotation on the stock market (Cornett et al., 2008), and the legal framework of the country of origin (La Porta et al., 2000). Consequently, I include several control variables to allow for the impact of these factors. These variables are listed and briefly defined in Table 1 .

\section{[Insert Table 1 here]}

\subsection{Data}

Tables $2 \mathrm{a}$ and $2 \mathrm{~b}$ summarise the construction of the sample for all banks and listed banks only, respectively. As reported in Table 2a, I collect consolidated bank account data for 741 banks (bank holding companies, hereafter BHCs; commercial banks; cooperative banks; and savings banks) located in either the U.S. or the European Union, hereafter EU (27 countries), ${ }^{8}$ from the Bureau Van Dijk Bankscope database. These banks are depository institutions, and therefore are subject to PCA in the U.S., but not in the EU.

\footnotetext{
${ }^{8}$ For the EU sub-sample, the only country for which there are no observations is Cyprus.
} 
Due to data availability on Thomson One Analytics (from which I collect daily closing prices), I am able to construct Nä̈ve $D D$ for 187 banks out of the original sample of 741 banks. Data on the dependent variable and all explanatory variables is available for 166 listed banks, which constitute our final sample.

\section{[Insert Tables 2a and 2b here]}

Tables 3 and 4 report the sample composition and descriptive statistics for the whole sample (Panel A) and the sub-sample of 166 listed banks (Panel B), respectively.

For Panel A, the majority of the banks in the sample are BHCs $(52 \%)$, followed by commercial banks (38\%). Most of the banks are located in the U.S. (59\%). The majority of the U.S. subsample consists of BHCs ( $81 \%$, but only $9 \%$ for the EU), while the majority of the EU subsample comprises commercial banks (65\%, but only $18 \%$ for the U.S.). Most of the sample consists of banks that were listed in at least one of the years comprising the sample period (53\%). There is no significant difference between the average DP of U.S. and EU banks, and between the average $D P$ of listed and unlisted banks. U.S. banks are less risky than EU banks in terms of $L n Z$ and SDROA, and they have a higher average Capital Ratio (ratio of equity to total assets). Consistent with this latter finding, the mean for the dummy variable Close is lower for U.S. banks than for EU banks. High Charter is, on average, larger for U.S. banks than for EU banks and it is, on average, larger for listed banks than for unlisted banks.

For Panel B, the statistics are similar, but the percentage of BHC and U.S. banks increases: they comprise $71 \%$ and $63 \%$ of the sample, respectively. Only one U.S. bank is not a BHC, while the EU sample is more heterogeneous, with a prevalence of commercial banks (62\%). U.S. banks have a significantly lower $D Y$ than EU banks. Similar to Panel A, U.S. banks are less risky than EU banks: on average, they have a significantly larger Nä̈ve $D D$ and a significantly lower $E D F$ and Close. On the other hand, the average High Charter is not significantly different from that of EU banks. 


\section{[Insert Tables 3 and 4 here]}

Pairwise correlation analysis (unreported for the sake of space) shows that for Panel A the variable $L n Z$ is negatively correlated with both SDROA and Close. This supports the validity of $L n Z$ as a proxy for risk taking. ${ }^{9}$ Banks with higher charter value exhibit higher $\operatorname{LnZ}$ values, suggesting that banks with high charter values have an incentive to avoid liquidation. For Panel B, Nä̈ve $D D$ is negatively correlated with $E D F$ (the coefficient is -0.985) and positively correlated with $L n Z$, suggesting that the three proxies are likely to identify high-risk banks in a consistent manner.

\section{Results}

This section presents the results of the GMM-SYS regressions as well as a battery of robustness tests. The results are reported separately for the whole sample (Panel A), and for a sub-sample of listed banks (Panel B).

The rest of this section is as follows. Section 4.1 presents the main results and robustness tests for the whole sample of 741 banks, and related sub-samples. Section 4.2 reports the results for the sub-sample of 166 listed banks, using Nä̈ve DD as a proxy for risk taking (I do not report the results for $\{-E D F\}$, since the results are the same) and dividends to market value of equity as a proxy for the payout ratio. Section 4.3 provides an analysis of the impact of share repurchases. Finally, Section 4.4 briefly discusses the main results in relation to the existing literature on dividend payout ratios in nonfinancial firms, and the banking literature on market discipline, capital adequacy regulation, and charter values.

\subsection{Results for the whole sample}

\footnotetext{
${ }^{9}$ The validity of $L n Z$ as a proxy for bank risk is also confirmed by a negative and significant correlation between $L n Z$ and the ratios of loan loss provisions to total loans (Altunbas et al., 2007).
} 
This section presents the main results of the GMM-SYS regressions. First, I run the GMM-SYS models with $\operatorname{LnZ}$ and the controls (I test only $\mathrm{H}_{1}$ ). Second, I test $\mathrm{H}_{1}$ and $\mathrm{H}_{2}$ by including in the regressions the dummy variable Close and the interaction term Close $\times$ LnZ. Third, I test $\mathrm{H}_{1}$ and $\mathrm{H}_{3}$ by including in the regressions the dummy variable High Charter and the interaction term High Charter $\times$ LnZ. Finally, I include LnZ, Close, High Charter, and the respective interaction terms to test $\mathrm{H}_{1}, \mathrm{H}_{2}$, and $\mathrm{H}_{3}$ in the same regressions. Since cooperative banks and savings banks may pursue objectives other than profit maximization, I report separately the results for regressions run on the whole sample and for BHC and commercial banks only. ${ }^{10}$

Table 5 reports estimation results for the dynamic panel data models. For the sake of exposition and to preserve space, the coefficients of the control variables are not included in Table 5. I allow for endogeneity with respect to both $D P(-1)$ and $L n Z$ using GMM instruments. The diagnostic statistics for all specifications are consistent with the assumptions of the GMM-SYS model.

For model 1, the coefficient of $\operatorname{LnZ}$ is negative and significant, supporting $\mathrm{H}_{1}$. For model 2, the coefficient of $L n Z$ is still negative and significant. However, the coefficient of Close is negative and significant, suggesting that banks that are close to the regulatory minimum make lower payout ratios with respect to well-capitalised banks, consistent with $\mathrm{H}_{2}$. For model 3, the coefficient of $\operatorname{LnZ}$ is still negative and significant. The coefficient of High Charter is negative and significant, supporting $\mathrm{H}_{3}$. Finally, the results for model 4 confirm those of the other specifications. ${ }^{11}$

\footnotetext{
${ }^{10}$ As a preliminary analysis, I investigate the appropriateness of $\operatorname{Ln} Z$ as a proxy for risk taking. I run a probit regression where the dependent variable is a dummy that takes on the value one if the bank equity to total assets ratio (ETA) was less than $4 \%$ or $5 \%$ in either 2008 or 2009 , and zero otherwise, and $L n Z$ in 2007 is the independent variable. The intuition is that, if $L n Z$ correctly proxies for risk taking, its current value should be negatively related to the future capital position of the bank. The coefficient on $L n Z$ is negative and significant at the $1 \%$ level when either $4 \%$ or $5 \%$ is considered as a threshold for ETA. When I repeat the analysis considering Tier 1 instead of ETA, the coefficient on $L n Z$ remains negative and strongly significant. These results suggest that, while $L n Z$ is an accountingbased measure, it perform reasonably well as a forward-looking risk measure. The results of this analysis are available from the author upon request.

${ }^{11}$ To understand whether the recession in 2008 and 2009 has had any impact on the dividend policy of banks, I extend the sample period from 2000-2007 to 2000-2009. The coefficients of a dummy variable, Crisis, which takes
} 
Considering the lower bound of the coefficient on $\operatorname{LnZ}(-0.081)$, an increase in $\operatorname{Ln} Z$ by one standard deviation (0.996) results in a decrease of $D P$ by about $8 \%$. Since the average $D P$ is $41 \%$, the results are economically significant for banks that are not close to the regulatory minimum and have low charter values. The results for Close and High Charter are also economically significant, and the results for the interaction terms suggest that capital adequacy requirements reduce moral hazard for banks with low capital ratios, while the desire to preserve the charter offsets the propensity to shift risk when the charter value is high. ${ }^{12}$

\section{[Insert table 5 here]}

As it is common in empirical studies, robustness checks are in order. I start with an investigation of possible heterogeneous effects due to differences in the legal framework of the country of origin, following the classification by La Porta et al. (1998). In this spirit, I estimate the regressions for countries with an English origin only (UK and U.S.), since banks from other countries may be too heterogeneous to be comparable. By focusing on these two countries only, I can rule out differences in dividend payout ratios that are due to poor protection of minority shareholders. As reported in Table 6, the results remain substantially unaltered regardless of whether the whole sub-sample of banks from Common Law countries or BHC and commercial banks only are considered.

\section{[Insert Table 6 here]}

Further investigation is needed with respect to the specific banking regulatory framework of the U.S. and the EU. In particular, U.S. banks may be subject to dividend restrictions due to PCA when their regulatory capital approaches the regulatory minimum. A bank cannot pay dividends

on the value 1 if the year is either 2008 or 2009 and 0 otherwise, are insignificant. The results for the main explanatory variables do not change substantially.

12 The results for the control variables (unreported but available upon request) are either insignificant or consistent with expectations, with the exception of the coefficient of $I P O$ for model 1, which is negative. 
if doing so would cause the bank to be undercapitalised. Every depository institution that is member of the Federal Deposit Insurance Corporation (FDIC) is subject to PCA.

I construct a dummy, PCA, which is equal to one if Close $=1$ and U.S. $=1$, and zero otherwise. As shown in Table 7, when I include PCA in the regressions, its coefficient is always negative and strongly significant, while the other main coefficients remain unaltered. Therefore, $P C A$ further reduce the risk that dividends be used as a risk-shifting device.

\section{[Insert table 7 here]}

I run further tests to assess the robustness of the main results. The results for these tests are not reported but are available upon request.

First, I run the regressions after winsorisation of the dependent variable and all continuous explanatory variables at the first and $99^{\text {th }}$ percentile. The results confirm those reported in Table 5. Second, when I replace $D P$ with $D E$ (dividends to equity) the results remain the same as those reported in Table 5. Finally, my results hold even after replacing the dummy variable Listed Bank with two other proxies for the IO-conflict: the variables Recorded Shareholders, and the dummies INDI and IND3 (which indicate the degree of independence of the bank from large shareholders).

\subsection{Results for a sub-sample of listed banks}

The results reported in Table 8 confirm a positive and significant relation between risk taking and the dividend payout ratio (i.e. the coefficient on Naïve DD is negative and significant). The diagnostic statistics support the validity of the assumptions for the GMM regressions. Considering the lower bound of the coefficient on Nä̈ve $D D$, an increase in Nä̈ve $D D$ by one standard deviation decreases $D Y$ by about $0.3 \%$. Since the average $D Y$ is $2.7 \%$, these results suggest that the impact of risk taking on the dividend payout ratio is economically significant for banks that are not close to the regulatory minimum and have low charter values. The 
coefficients on High Charter and High Charter $\times$ Nä̈ve DD are significant and with the expected sign. However, the coefficients on Close and Close $\times$ Nä̈ve DD are insignificant, as a result of a very low number of observations for which Close takes on the value one (19 observations for 15 banks).

Similar to what reported in Tables 6 and 7 for the whole sample, the results remain substantially the same when only banks from the US and the UK are considered, and when $P C A$ is included in the regressions. However, in this case the coefficient on $P C A$ is insignificant. The results are also robust to the proxy for the IO-conflict (Recorded Shareholders, and the dummies INDI and IND3), and to inclusion of the 2008-2009 period.

\section{[Insert table 8 here]}

\subsection{Extension: The impact of share repurchases}

As a further robustness test, I examine the impact of share repurchases. Share repurchases are non-binding (unlike ordinary dividends), and therefore do not contain the same signalling content of dividends (Allen et al., 2009). Due to the binding nature of dividend payments, they can address agency conflicts more effectively than share repurchases (John and Knyazeva, 2006; De Cesari, 2012). Share repurchases, on the other hand, tend to occur to pay out transitory earnings (Jagannathan et al., 2000). Because share repurchases can harm the capital adequacy of a bank, and restrictions on both dividends and share repurchases are now included in the Basel III framework, I incorporate share repurchases in the analysis to further improve the robustness of my findings. ${ }^{13}$

I calculate the payout from share repurchases $(S P)$ as the total number of shares repurchased times the average price using data from SNL Financial. I merge this dataset with data from

\footnotetext{
${ }^{13}$ While share repurchases tend to be rather common in the U.S. and (to a lesser extent) in the UK, in continental Europe share repurchases are rare, and in certain countries, such as France and Germany, they were illegal or subject to very strict regulation until the late nineties (Rau and Vermaelen, 2002).
} 
Thomson One (stock price data), and Bankscope (dividends and other accounting variables). I calculate the total payout ratio as the sum of $D Y$ and $S Y$ ( $S P$ divided by the market value of equity), and I denote it $T P .{ }^{14}$ Table 9 reports the results of the regressions for $T P$. The results are substantially the same as those reported in Table 8 for $D Y$.

\section{[Insert table 9 here]}

\subsection{Discussion of the main results}

My results suggest that banks that are closer to default tend to have higher payout ratios, regardless of the proxy employed for the payout ratio or for bank risk-taking.

Since for banks close to the regulatory minimum this positive relation is negligible, these results do not necessarily suggest that capital adequacy regulation prior to Basel II was ineffective in curbing risk-shifting deriving from high dividend payout ratios. However, if capital requirements are not highly correlated with the actual risk taking of the bank, high risk taking and high dividend payout ratios may persist. In unreported results, I find that a negative and significant correlation exists between Close and $L n Z$ and Nä̈ve $D D$, while there is a positive and significant correlation between Close and EDF. Therefore, to the extent that $L n Z$, Nä̈ve DD, and $E D F$ capture correctly bank risk-taking, it is unlikely that banks close to default increased their dividend payout ratio during the sample period. These results are not necessarily inconsistent with those presented by Acharya et al. (2011), who suggests that, during the financial crisis, banks kept paying dividends despite anticipating large losses in their portfolios. Banks may have kept paying dividends without increasing the dividend payout ratio. Therefore, my results should not be interpreted as evidence that further dividend restrictions for undercapitalised banks are unnecessary.

\footnotetext{
${ }^{14}$ Since $T P$ is highly leptokurtic (kurtosis is over 640) and positively skewed (skewness is over 20), I winsorise the data at the $95^{\text {th }}$ percentile before running the regressions. As a result of winsorisation, excess sample kurtosis is eliminated and sample skewness is around 0.6.
} 
The results for the sample of both listed and unlisted banks suggest that U.S. banks decrease payout ratios to a greater extent than EU banks when they are close to the minimum capital requirement. This finding is consistent with the view that PCA are useful in decreasing moral hazard, and supports the recent changes in the Basel Accord (Basel III) that impose progressive dividend restrictions on banks that are undercapitalised (Brunnermeier et al., 2009; Caruana, 2010). In light of the results on the impact of charter value on payout ratios, dividend restrictions would be particularly useful in periods of high competition, when charter values are low (Keeley, 1990), or during periods of weak economic growth.

My results are also in line with the predictions put forward by Acharya et al. (2012), who model the theoretical relation between risk-shifting incentives, dividends, and charter values. Acharya et al. (2012) show that during financial crises, when charter values are low, banks may be incentivised to implement dividend policies inconsistent with maximization of social welfare. To the best of my knowledge, this is the first paper that provides evidence on the importance of different types of capital adequacy regulations and charter values on the relation between bank dividend policy and risk taking.

My findings also complement recent contributions on the relation between dividends, competition (which affects charter values), and business risk. Booth and Zhou (2009) provide evidence that firms in highly competitive environments face higher levels of risk, and this may in turn result in a lower likelihood of a dividend and smaller dividend payouts for the firms that decide to pay dividends. Similarly, Zhou et al. (2013) argue that the phenomenon of disappearing dividends in the U.S. (Fama and French, 2001) could be associated with competition from foreign firms. My findings show that when risk-shifting incentives are distorted by regulation (such as deposit insurance), stronger competition that decreases charter values (Keeley, 1990) increases dividend payout ratios. 
Finally, my findings are related to the growing body of literature on 'market discipline' in banks (among others, Ellis and Flannery, 1992; Goyal, 2005; Schaeck et al., 2012). My results show that capital requirements are effective in reducing risk-shifting incentives, which can be interpreted as evidence of regulator discipline. In addition to this, I provide evidence that a high ratio of customer deposits to total assets has a negative impact on the positive relation between bank risk-taking and dividend payout ratios. This latter finding can be interpreted as evidence of 'depositor discipline'.

\section{Concluding Remarks}

Previous literature has reported that banks kept paying dividends during the recent financial crisis, despite a call from regulators to restrain dividend payments to maintain financial stability and foster economic recovery through lending growth. This issue is important because an excessively generous bank dividend policy is inconsistent with maximization of social welfare: High dividend payout ratios can effectively transfer wealth from depositors and the taxpayer to bank shareholders (risk-shifting), resulting in substantial negative externalities in periods of economic slowdown.

In this paper, I have provided robust evidence that dividend payout ratios and bank risk-taking are positively correlated, contrary to the received wisdom reported in the literature on nonfinancial firms. However, such correlation is affected by the regulatory capital ratio and the charter value of the bank: Capital adequacy requirements and a high charter value reduce riskshifting.

My findings bear important policy implications. First, because of regulatory capital management practices, the previous versions of the Basel framework could result in a belated response to risk-shifting, especially in countries where PCA do not exist. Under Basel III rules, banks must maintain a conservation buffer consisting of Tier 1 capital only, reducing the likelihood of regulatory capital management. If the buffer is breached, earnings distributions 
(such as dividends and share repurchases) are capped. Therefore, Basel III should reduce further the likelihood of risk-shifting.

Second, in light of the findings on the role of charter values, pro-cyclicality in bank charter values should also be considered. In this respect, the new countercyclical capital buffer introduced by Basel III, which also entails restrictions on dividends and share repurchases if the buffer is breached, may only partially address the problem. Such countercyclical requirement would reduce dividend payout ratios during periods of economic growth, helping banks to withstand macroeconomic shocks. However, it is during economic slowdowns that bank charter values are low and risk-shifting through dividends and share repurchases is more likely. My findings suggest that a more thorough theoretical analysis of the impact of the countercyclical capital buffer on risk-shifting incentives is called for. Empirical studies could follow in the forthcoming years, after implementation of Basel III.

Further research could also investigate the impact of corporate governance and ownership structure on risk-shifting incentives. For instance, the literature on managerial entrenchment predicts higher dividend payout ratios for firms where the executives are entrenched. Thus, for banks where managers are entrenched the problem of risk-shifting could be more intense, and regulatory monitoring should increase accordingly. Similarly, in group-affiliated banks outside shareholders could require higher dividend payout ratios to dampen expropriation from controlling shareholders. An assessment of the costs and benefits of restrictions on dividends and share repurchases in such cases is a challenging task, because stronger protection of depositors may lead to expropriation of outside shareholders. Theoretical and empirical contributions in this direction could help policy makers develop regulations that strike a balance between safeguarding the interest of outside shareholders and maintaining financial stability. 


\section{Appendix}

Analytical explanation of the relationship between the value of common equity, dividends, and risk.

In this appendix I give a brief account of the models by Merton $(1974,1977)$ on the pricing of corporate debt and of the cost of deposit insurance, and how they relate to dividend payments and risk. For details regarding the models, I refer the reader to Merton $(1974,1977)$, and Ronn and Verma (1986).

The model on the pricing of corporate debt developed by Merton (1974) is based on the isomorphic relation between common equity of a levered firm and a common stock call option. The model on the pricing of deposit insurance developed by Merton (1977) relies upon the isomorphic relation between loan guarantees and common stock put options, and can be applied to any guarantee of a third party on behalf of the borrower, such as guarantees of a parent company for a loan made by a third party to one of its subsidiaries.

Assume that the value of assets of a bank at time $t\left(\mathrm{~A}_{\mathrm{t}}\right)$ follows a Geometric Brownian motion:

$$
\mathrm{d} l n\left(\mathrm{~A}_{\mathrm{t}}\right)=\mu \mathrm{dt}+\sigma \mathrm{dW}_{\mathrm{t}}
$$

where $\mu$ is the instantaneous expected return on assets, $\sigma$ is the instantaneous standard deviation of returns, and $\mathrm{W}_{\mathrm{t}}$ is a Wiener process. The payoff of a European call option with strike price $\mathrm{X}$ on the expiration date, $\mathrm{t}^{*}$, is the greater between 0 and the difference between $\mathrm{A}_{\mathrm{t}^{*}}$ and $\mathrm{X}$, or $\operatorname{MAX}\left[0, \mathrm{~A}_{\mathrm{t}^{*}}-\mathrm{X}\right]$, while the payoff of a European put option is $\operatorname{MAX}\left[0, \mathrm{X}-\mathrm{A}_{\mathrm{t}^{*}}\right]$. In a frictionless market, the 'no arbitrage opportunities' condition (Black and Scholes, 1972) holds: ${ }^{15}$

$$
\mathrm{C}_{\mathrm{t}}=\mathrm{A}_{\mathrm{t}} \mathrm{N}\left(\mathrm{d}_{1}\right)-\mathrm{Xe} \mathrm{e}^{-\mathrm{TT}} \mathrm{N}\left(\mathrm{d}_{2}\right)
$$

\footnotetext{
${ }^{15}$ The 'no arbitrage opportunities condition' states that ' $[. .$.$] in equilibrium a riskless hedge cannot yield a return$ greater than the short term interest rate in the market, the option must be priced such that market participants could not establish this hedge and expect to realize a sure profit.' (Black and Scholes, 1972, p.400).
} 


$$
\begin{aligned}
& \mathrm{d}_{1}=\left[\ln \left(\mathrm{A}_{\mathrm{t}} / \mathrm{X}\right)+\left(\mathrm{r}+0.5 \sigma^{2}\right) \mathrm{T}\right] / \sigma \mathrm{T}^{0.5} \\
& \mathrm{~d}_{2}=\mathrm{d}_{1}-\sigma \mathrm{T}^{0.5} \\
& \mathrm{P}_{\mathrm{t}}=\mathrm{C}_{\mathrm{t}}+\mathrm{Xe}^{-\mathrm{rT}}-\mathrm{A}_{\mathrm{t}}
\end{aligned}
$$

where $C_{t}$ is the price of the call option (for one share), $P_{t}$ is the price of the put option (for the same share), $\mathrm{r}$ is the short-term rate of interest, $\mathrm{T}$ is the duration of the option (time to expiration), and $\mathrm{N}($.$) is the value of the cumulative distribution function of the standard Normal$ distribution. According to Merton (1977), the face value of debt of a corporation, D, can be seen as the strike price of a call, or $\mathrm{X}$ in equation (A2). In such circumstances, the equity value of the bank, $\mathrm{E}_{\mathrm{t}}$, can be calculated using:

$$
\mathrm{E}_{\mathrm{t}}=\mathrm{A}_{\mathrm{t}} \mathrm{N}\left(\mathrm{d}_{1}\right)-\mathrm{De}^{-\mathrm{rT}} \mathrm{N}\left(\mathrm{d}_{2}\right)
$$

where $D$ is the face value of debt. The cost of deposit insurance, $G_{t}$, can be modelled according to (A3), but with an adjustment to consider the fraction of the bank liabilities that consists of insured deposits, $\eta=D_{1} / \mathrm{D}$. If all pre-insurance debt is of equal seniority, depositors (in the absence of deposit insurance) will receive the lower between the future value of deposits, $\mathrm{FV}\left(\mathrm{D}_{1}\right)$, and the pro-rated fraction of the value of the total assets of the bank, $A_{t} \eta$. The payoff generated by the deposit insurance at maturity is $\operatorname{MAX}\left[0, \mathrm{FV}\left(\mathrm{D}_{1}\right)-\mathrm{A}_{t} \eta\right]$ (Ronn and Verma, 1986). The deposit insurance premium can be modelled as follows:

$$
\begin{aligned}
& \mathrm{G}_{\mathrm{t}}=\mathrm{N}\left(\mathrm{h}_{2}\right)-(1-\delta)\left(\mathrm{A}_{\mathrm{t}} / \mathrm{De}^{-\mathrm{rT}}\right) \mathrm{N}\left(\mathrm{h}_{1}\right) \\
& \mathrm{h}_{1}=\left\{\ln \left[\mathrm{D} / \mathrm{A}_{\mathrm{t}}(1-\delta)\right]-\mathrm{T}\left(\mathrm{r}+0.5 \sigma^{2}\right)\right\} / \sigma \mathrm{T}^{0.5} \\
& \mathrm{~h}_{2}=\mathrm{h}_{1}+\sigma \mathrm{T}^{0.5}
\end{aligned}
$$

where $G_{t}$ is the premium of the deposit insurance per each dollar of insured deposits, equivalent to the value of a put with a strike price equal to total debt (D) divided by $\mathrm{D}_{1}, \delta$ is the dividend 
per dollar of $A_{t}$, assuming that dividends are paid once for each period. Equation (A5) shows that, ceteris paribus, a larger $\delta$ increases $G_{t}$ because it decreases $A_{t}$. Note that in equation (A4) dividends do not decrease the value of equity because equity is dividend-protected (Ronn and Verma, 1986). If deposit insurance exists in the banking system, banks that pay dividends can increase the value of deposit insurance by paying dividends. Banks are also incentivised to increase the debt-to-assets ratio, because this decreases $\mathrm{A}_{t} / \mathrm{De}^{-\mathrm{rT}}$.

The value of a debt in a leveraged bank which pays dividends is:

$$
\begin{aligned}
& \mathrm{F}_{\mathrm{t}}=\mathrm{De}^{-\mathrm{rT}}\left[\mathrm{N}\left(\mathrm{f}_{2}\right)+(1-\delta)\left(\mathrm{A}_{t} / \mathrm{De}^{-\mathrm{rT}}\right) \mathrm{N}\left(\mathrm{f}_{1}\right)\right] \\
& \mathrm{f}_{1}=-\left\{0.5 \sigma^{2} \mathrm{~T}-\ln \left[\mathrm{De}^{-\mathrm{rT}} / \mathrm{A}_{\mathrm{t}}(1-\delta)\right]\right\} / \sigma \mathrm{T}^{0.5} \\
& \mathrm{f}_{2}=-\left\{0.5 \sigma^{2} \mathrm{~T}+\ln \left[\mathrm{De}^{-\mathrm{rT}} / \mathrm{A}_{\mathrm{t}}(1-\delta)\right]\right\} / \sigma \mathrm{T}^{0.5}
\end{aligned}
$$

Therefore, dividends reduce the value of bank assets and the overall amount that debt holders can claim in the event of liquidation. Dividends reduce the value of debt because debt, unlike equity, is not dividend-protected. Given the face value of uninsured debt, $D_{2}=D-D_{1}$, dividends decrease the probability that uninsured debt holders will be repaid if the bank collapses. Assume that, in the event of a default, all insured depositors are paid by the deposit insurance scheme, so that uninsured debt holder can claim the total of the assets of the bank, $A_{t}$. Then, the future value of uninsured debt for banks that do not pay dividends is:

$$
\operatorname{FV}\left(D_{2}\right)=\min \left[A_{t}, D_{2}\right]
$$

For banks that pay dividends, the future value of uninsured debt is:

$$
\mathrm{FV}\left(\mathrm{D}_{2}\right)^{*}=\min \left[(1-\delta) \mathrm{A}_{\mathrm{t}}, \mathrm{D}_{2}\right]
$$

Note that for any $\delta>0$, if $(1-\delta) \mathrm{A}_{\mathrm{t}}<\mathrm{D}_{2}$, then $\mathrm{FV}\left(\mathrm{D}_{2}\right)^{*}<\mathrm{FV}\left(\mathrm{D}_{2}\right)$. Paying dividends benefits common shareholders because they receive cash while debt holders do not, and dividends 
reduce the probability that uninsured debt holders will be paid in full. This effect is stronger for banks for which $D_{2}$ is large. As $D_{2}$ increase (for instance, because of the issuance of hybrid capital instruments, as in Acharya et al, 2011), $\operatorname{De}^{-\mathrm{rT}} \mathrm{N}\left(\mathrm{d}_{2}\right)$ in equation (A4) approaches $\mathrm{A}_{t} \mathrm{~N}\left(\mathrm{~d}_{1}\right)$, and $E_{t} \rightarrow 0$. Therefore, banks may increase the debt-to-assets ratio to increase $G_{t}$ (to the extent that this is allowed by capital adequacy regulation), but in so doing the value of equity would decrease, as it would be for a call option with a larger strike price. Banks with $E_{t} \rightarrow 0$ may attempt to increase $\mathrm{E}_{\mathrm{t}}$ by increasing business risk, which in the BS-model can be represented by $\sigma$ (Merton, 1973). More risk increases the payoff of a call option conditional on the option being exercised. This can be easily shown taking the first derivative of (A4) with respect to $\sigma$ (also called Vega): ${ }^{16}$

$$
\partial \mathrm{E}_{\mathrm{t}} / \partial \sigma=\mathrm{A}_{\mathrm{t}} \mathrm{n}\left(\mathrm{d}_{1}\right) \mathrm{T}^{0.5}
$$

Where $\mathrm{n}($.$) is the probability density function of the standard Normal distribution. Given that \mathrm{A}_{\mathrm{t}}$ $\geq 0, \mathrm{n}\left(\mathrm{d}_{1}\right) \geq 0$, and $\mathrm{T}^{0.5} \geq 0$, it follows that an increase in business risk brings about a higher value of $E_{t}$. What is the impact of business risk on the current value of debt, $F_{t}$ ? As shown in Merton (1974), $F_{t}=A_{t}-E_{t}$. Therefore, there is a negative relation between $F_{t}$ and $E_{t}$. Due to the positive relation between $\sigma$ and $\mathrm{E}_{\mathrm{t}}$ (equation A9), it follows that $\mathrm{F}_{\mathrm{t}}$ is negatively related to $\sigma$, i.e. an increase in business risk decreases the current value of the debt (see also Merton, 1974, p. 455). Therefore, as said in the introduction, ceteris paribus dividends and the issuance of debt decrease the capital ratio and incentivise risk taking.

\footnotetext{
${ }^{16}$ For a derivation of (A9), please refer to Garven (2009), pp. 13-14.
} 


\section{References}

Acharya, V. V., Gujral, I., Kulkarni, N. and Shin, H. S., 'Dividends and bank capital in the financial crisis of 2007-2009', NBER Working Paper, 2011.

Acharya, V. V., Le, H., and Shin, H. S., 'Bank capital and dividend externalities,' Princeton University Working Paper, 2012.

Akerlof, G. A., and Romer, P. M., 'Looting: the economic underworld of bankruptcy for profit', Brookings Papers on Economic Activity (Macroeconomics), 1993, pp. 1-73.

Allen L., Gottesman A., Saunders A., Tang Y. (2009). The role of banks in dividend policy. New York University, Stern School of Business Working Paper.

Altunbas, Y., Carbo, S., Gardener, E. P. M. and Molyneux, P., 'Examining the relations between capital, risk and efficiency in European banking', European Financial Management, Vol. 13(1), 2007, pp. 49-70.

Andres, C., Betzer, A., Goergen, M. and Renneboog, L., 'Dividend policy of German firms. A panel data analysis of partial adjustment models', Journal of Empirical Finance, Vol. 16, 2009. pp. 175-87.

Arellano, M. and Bond, S., 'Some tests of specification for panel data: Monte Carlo evidence and an application to employment equations', Review of Economic Studies, Vol. 58, 1991, 27797.

Arellano, M. and Bover, O., 'Another look at the instrumental variable estimation of errorcomponents models', Journal of Econometrics, Vol. 68, 1995, pp. 29-51.

Baker, H. K., Powell, G. E., and Veit, E. T., 'Revisiting the dividend puzzle: Do all of the pieces now fit?' Review of Financial Economics, Vol. 11, 2002, pp. 241-261.

Baker, M., and Wurgler, J., 'Appearing and disappearing dividends: The link to catering incentives', Journal of Financial Economics, Vol. 73(2), 2004, pp. 271-288. 
Beck, T., De Jonghe, O. and Shepens, G., 'Bank competition and stability: Cross-country heterogeneity', Journal of Financial Intermediation, 2013, forthcoming.

Bessler, W. and Nohel, T., 'The stock-market reaction to dividend cuts and omissions by commercial banks', Journal of Banking and Finance, Vol. 20(9), 1996, pp. 1485-508.

Bessler, W. and Nohel, T., 'Asymmetric information, dividend reductions and contagion effects in bank stock returns', Journal of Banking and Finance, Vol. 24(9), 2000, pp. 1831-48.

Bharath, S. T., and Shumway, T., 'Forecasting default with the Merton Distance to Default Model', Review of Financial Studies, Vol. 21 (3), 2008, pp. 1339-1369.

Bhattacharya, S. 'Imperfect information, dividend policy, and "The bird in the hand" fallacy', Bell Journal of economics, Vol. 10 (1), 1979, pp. 259-270.

Black, F., and Scholes, M., 'The valuation of option contracts and a test of market efficiency' The Journal of Finance, Vol. 27(2), 1972, pp. 399-417.

Blundell, R. and Bond, S., 'Initial conditions and moment restrictions in dynamic panel data models', Journal of Econometrics, Vol. 87, 1998, pp. 115-43.

Booth, L., and Zhou, J., 'Market power and dividend policy: A risk-based perspective', University of Toronto Working Paper, 2009.

Brennan, M., 'Taxes, market valuation and financial policy', National Tax Journal, Vol. 23, 1970, pp. 417-429.

Brunnermeier, M., Crocket, A., Goodhart, C., Persaud, A. D. Shin, H. S., 'The fundamental principles of financial regulation', Geneva Reports on the World Economy 11, (CEPR, 2009).

Caruana, J., 'Basel III: towards a safer financial system', Speech at the 3rd Santander International Banking Conference, 15 September 2010, Madrid.

Cebenoyan, A. S., Cooperman E. S., and Register, C. A., 'Ownership structure, charter value, and risk-taking behaviour of thrifts', Financial Management, Vol. 28(1), 1999, pp. 43-60. 
Chay, J. B. and Suh, J. 'Payout policy and cash-flow uncertainty', Journal of Financial Economics, Vol. 93, 2009, pp. 88-107.

Cornett, M. M., Fayman, A., Marcus, A. J. and Tehranian, H., 'Dividend signalling: evidence from bank IPOs', Working Paper (Boston University, 2008).

DeAngelo, H. and DeAngelo, L., 'Payout policy pedagogy: what matters and why', European Financial Management, Vol. 13(1), 2007, pp. 11-27.

DeAngelo, H., DeAngelo, L. and Skinner, D. J., 'Are dividends disappearing? Dividend concentration and the consolidation of earnings', Journal of Financial Economics, Vol. 72, 2004, pp. 425-56.

DeAngelo, H., DeAngelo, L. and Stulz, R. M., 'Dividend policy and the earned/contributed capital mix: a test of the life-cycle theory', Journal of Financial Economics, Vol. 81, 2006, pp. $227-54$.

De Cesari, A., 'Expropriation of minority shareholders and payout policy', British Accounting Review, Vol. 44(4), 2012, pp. 207-220.

Denis, D. J. and Osobov, I., 'Why do firms pay dividends? International evidence on the determinants of dividend policy', Journal of Financial Economics, Vol. 89, 2008, pp. 62-82.

Easterbrook, F., 'Two agency cost explanations of dividends', American Economic Review, Vol. 72, 1984, pp. 650-58.

Ellis, D. M., and Flannery, M. J., 'Does the debt market assess large banks' risk? Time series evidence from money center CDs,' Journal of Monetary Economics, Vol. 30, 1992, pp. 481502.

Faccio, M., Lang, L. H. P. and Young, L., 'Dividends and expropriation', American Economic Review, Vol. 91(1), 2001, pp. 54-78. 
Fama, E. F. and French, K. R., 'Disappearing dividends: changing firm characteristics or lower propensity to pay?' Journal of Financial Economics, Vol. 60, 2001, pp. 3-43.

Farrar, D. E., and Selwyn, L. L., 'Taxes, corporate financial policy and return to investors', National Tax Journal, Vol. 20, 1967, pp. 444-454.

Garven, J. R., 'Derivation and comparative statics of the Black-Scholes call and put option pricing formula', Hankamer School of Business Working Paper, 2010.

Goyal, V. K., 'Market discipline of bank risk: evidence from subordinated debt contracts', Journal of Financial Intermediation, Vol. 14, 2005, pp. 318-50.

Gropp, R. and Heider, F., 'The determinants of bank capital structure', Review of Finance, Vol. 14(4), 2010, pp. 587-622.

Grullon, G., Michaely, R., Benartzi, S., and Thaler, R. H., 'Dividend changes do not signal changes in future profitability', Journal of Business, Vol. 78, 2005, pp. 1659-1682.

Hagendorff, J., and Vallascas, F., 'CEO pay incentives and risk-taking: Evidence from bank acquisitions,' Journal of Corporate Finance, Vol. 17, 1078-1095.

Hansen, L., 'Large sample properties of generalized method of moments estimators', Econometrica, Vol. 50, 1982, pp. 1029-54.

Hansen, R. S., Kumar, R., and Shome, D. K., 'Dividend policy and corporate monitoring: Evidence from the regulated electric utility industry', Financial Management, Vol. 23(1), 16-22. Healy P. M., Palepu K. G., 'Earnings information conveyed by dividend initiations and omissions', Journal of Financial Economics, Vol. 21, 1988, pp. 149-175.

Hellmann, T. F., Murdock, K. C. and Stiglitz, J. E., 'Liberalization, moral hazard in banking, and prudential regulation: are capital adequacy requirements enough?' American Economic Review, Vol. 90(1), 2000, pp. 147-65. 
Hoberg, G., and Prabhala, N. R., 'Disappearing dividends, catering, and risk', Review of Financial Studies, Vol. 22, 2009, pp. 79-116.

Hutchison, D. E., and Pennacchi, G. G., 'Measuring rents and interest rate risk in imperfect capital markets: the case of retail bank deposits', Journal of Financial and Quantitative Analisis, 1996, Vol. 31, 399-417.

Jagannathan, M., Stephens, C. P., and Weisbach, M. S., 'Financial flexibility and the choice between dividends and stock repurchases', Journal of Financial Economics, Vol. 57, 2000, pp. $355-384$

James, C., 'The losses realized in bank failures', Journal of Finance, Vol. 46(4), 1991, pp. $1223-1242$.

Jensen, M. C., 'Agency costs of free cash flow, corporate finance and takeovers', American Economic Review, Vol. 76, 1986, pp. 323-39.

John, K., and Knyazeva, A., 'Payout policy, agency conflicts, and corporate governance', New York University Working Paper.

John, K., and Williams, J., 'Dividends, dilution, and taxes: a signaling equilibrium', Journal of Finance, Vol. 40, 1985, pp. 1053-1070.

Keeley, M. C., 'Deposit insurance, risk, and market power in banking', American Economic Review, Vol. 80(5), 1990, pp. 1183-200.

Keen, Jr. H., 'The impact of a dividend cut announcements on bank share prices', Journal of Bank Research, 1983, Winter, pp. 274-281.

Khan, T., 'Company dividends and ownership structure: evidence from UK panel data', Economic Journal, Vol. 116, 2006, pp. C172-89.

Laeven, L. and Levine, R., 'Bank governance, regulation and risk taking', Journal of Financial Economics, Vol. 93(2), 2009, pp. 259-75. 
La Porta, R., Lopez-de-Silanes, F., Shleifer, A., and Vishny, R. W., 'Law and finance', Journal of Political Economy, Vol. 106(6), 1998, 1113-1155.

La Porta, R., Lopez-de-Silanes, F., Shleifer, A. and Vishny, R. W., 'Agency problems and dividend policies around the world', Journal of Finance, Vol. 55(1), 2000, pp. 1-33.

Lease, R. C., John, K., Kalay, A., Loewenstein, U., and Sarig, O. H., 'Dividend policy', Harvard Business School Press, Boston, 2000.

Li, K. and Zhao, X., 'Asymmetric information and dividend policy', Financial Management, Vol. 37, 2008, pp. 673-94.

Lintner, J., 'Distribution of incomes of corporations among dividends, retained earnings and taxes', American Economic Review, Vol. 46(2), 1956, pp. 97-113.

Marcus, A. J., 'Deregulation and bank financial policy', Journal of Banking and Finance, Vol. 8, 1984, pp. 114-16.

Merton, R. C., 'Theory of rational option pricing', Bell Journal of Economics and Management Science, Vol. 4, 1973, pp. 141-183.

Merton, R. C., 'On the pricing of corporate debt: the risk structure of interest rates', Journal of Finance, Vol. 29, 1974, pp. 449-70.

Merton, R. C., 'An analytical derivation of the cost of deposit insurance and loan guarantees', Journal of Banking and Finance, Vol. 1(2), 1977, pp. 3-11.

Miller, M., and Modigliani, F., 'Dividend policy, growth, and the valuation of shares', Journal of Business, Vol. 34, 1961, pp. 411-433.

Miller, M., and Rock, K., 'Dividend policy under asymmetric information', Journal of Finance, Vol. 40, 1985, pp. 1031-1051.

Nickell S., 'Biases in dynamic models with fixed effects', Econometrica, Vol. 49, 1981, 14171426. 
Polonchek, J., Slovin, M. B., and Sushka, M. E., 'Valuation effects of commercial bank securities offerings', Journal of Banking and Finance, Vol. 13, 1989, pp. 443-461.

Rau, R., and Vermaelen, T., 'Regulation, taxes, and share repurchases in the United Kingdom', Journal of Business, Vol. 75(2), 2002, pp. 245-282.

Ronn, E. I. and Verma, A. K., 'Pricing risk-adjusted deposit insurance: an option based model', Journal of Finance, Vol. 41(4), 1986, pp. 871-895.

Roodman, D. "How to do xtabond2: an introduction to "difference" and "system" GMM in Stata', Center for Global Development, Working Paper No. 103, December (2006).

Roodman, D., 'A note on the theme of too many instruments', Oxford Bulletin of Economics and Statistics, Vol. 71(1), 2009, pp. 135-58.

Rozeff, M. S., 'Growth, Beta and agency costs as determinants of dividend payout ratios', Journal of Financial Research, Vol. 5, 1982, 249-259.

Schaeck, K., Čihák, M., Maechler, A. and Stolz, S., 'Who disciplines bank managers?' Review of Finance, 2012, forthcoming.

Turner, J. D., Ye, Q., and Zhan, W., 'Why do firms pay dividends?: Evidence from an early and unregulated capital market', Review of Finance, 2013, forthcoming.

Von Eije, H. and Megginson, W., 'Dividends and share repurchases in the European Union', Journal of Financial Economics, Vol. 89, pp. 347-374.

Windmeijer, F., 'A finite sample correction for the variance of linear two-step GMM estimators', Journal of Econometrics, Vol. 126, 2005, pp. 25-51.

Zhou, J., Booth, L., and Chang, B., 'Import competition and disappearing dividends', Journal of International Business Studies, Vol. 44, 2013, pp. 138-154. 
Table 1. Explanatory variables in regressions on payout ratios $(D P, D Y$, and $T P)$ : Definitions and expected sign of the coefficients.

\begin{tabular}{|c|c|c|}
\hline Proxy & Definition & $\begin{array}{l}\text { Expected sign } \\
\text { of the coefficient }\end{array}$ \\
\hline $\operatorname{LnZ}$ & $\begin{array}{l}\text { Natural logarithm of the Z-score: } \\
L n Z_{\mathrm{it}}=\ln \left(\mathrm{Z}_{\mathrm{it}}\right)=\ln \left[\left(R O A_{\mathrm{it}}+E_{\mathrm{it}} / T A_{\mathrm{it}}\right) / S D R O A_{\mathrm{it}}\right] \\
\text { where Return on Assets (ROA) is the net income of bank } i \text { in period } t \text { plus the loan } \\
\text { loss provision of bank } i \text { in period } t \text { divided by the total assets of bank } i \text { in period } t \text {. } \\
\text { The variable } E_{\mathrm{it}} \text { is the total equity (including common and preferred share capital } \\
\text { and equity reserves) and } T A_{\mathrm{it}} \text { is the total assets of bank } i \text { in period } t \text {. Finally, ROA } \\
\text { volatility is calculated as } \\
S D R O \mathrm{~A}_{\mathrm{it}}=\sqrt{\frac{1}{\mathrm{~T}-1} \sum_{\mathrm{t}=-1}^{\mathrm{t}+1}\left(R O A_{\mathrm{it}}-\overline{R O A_{\mathrm{i}}}\right)^{2}} \text { with } \overline{R O A_{\mathrm{i}}}=\frac{1}{\mathrm{~T}} \sum_{\mathrm{t}=-1}^{\mathrm{T}-2} R O A_{\mathrm{it}} \text { and } \mathrm{T}=3 \text {. }\end{array}$ & $\begin{array}{l}\text { Negative } \\
\text { (risk-shifting } \\
\text { hypothesis) }\end{array}$ \\
\hline Nä̈ve DD & 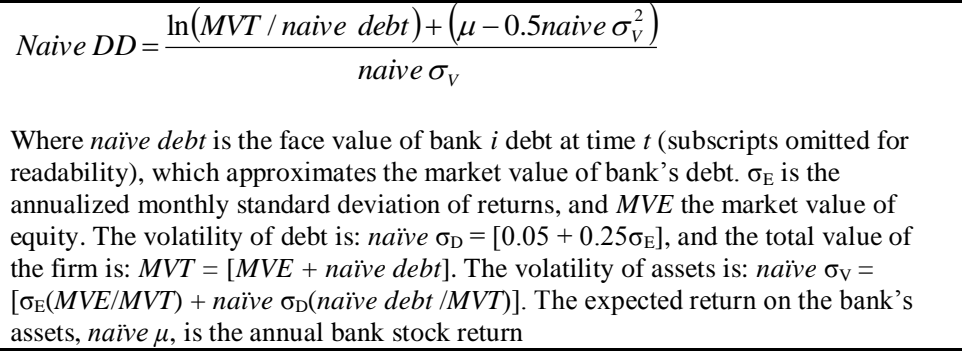 & $\begin{array}{l}\text { Negative } \\
\text { (risk-shifting } \\
\text { hypothesis) }\end{array}$ \\
\hline $\begin{array}{l}\text { Expected Default } \\
\text { Frequency }(\text { EDF })\end{array}$ & $\begin{array}{l}\Phi(- \text { Nä̈ve } D D) \text {, where } \Phi(.) \text { is the cumulative standard normal distribution function. } \\
\text { Nä̈ve } D D\end{array}$ & $\begin{array}{l}\text { Positive (risk- } \\
\text { shifting } \\
\text { hypothesis) } \\
\text { Negative for } \\
(-E D F)\end{array}$ \\
\hline Close & Dummy variable: 1 if Tier $1<6 \%$ or TCR $<10 \%$, and 0 otherwise & $\begin{array}{l}\text { Negative } \\
\text { (opportunity cost } \\
\text { hypothesis) }\end{array}$ \\
\hline High Charter & $\begin{array}{l}\text { Dummy variable: } 1 \text { if the ratio of customer deposits to total assets is larger than the } \\
\text { sample median, and } 0 \text { otherwise. For the subsample of } 166 \text { listed banks, the dummy } \\
\text { is based on the market-to-book ratio. }\end{array}$ & $\begin{array}{l}\text { Negative (charter } \\
\text { value hypothesis) }\end{array}$ \\
\hline \multicolumn{3}{|c|}{ Proxies for Insider-Outsider (IO) conflict and other control variables } \\
\hline $\begin{array}{l}\text { Recorded } \\
\text { Shareholders }\end{array}$ & Number of recorded shareholders in $2009^{\mathrm{c}}$ & Positive \\
\hline Listed Bank & $\begin{array}{l}\text { Dummy variable: } 1 \text { if bank } i \text { is listed on the stock market in period } t \text {, and } 0 \\
\text { otherwise }\end{array}$ & Positive/Negative \\
\hline INDI & $\begin{array}{l}\text { Dummy variable: } 1 \text { if there is no shareholder with more than } 25 \% \text { of total } \\
\text { ownership in } 2009,{ }^{\text {c }} \text { and } 0 \text { otherwise }\end{array}$ & Positive \\
\hline IND2 & $\begin{array}{l}\text { Dummy variable: } 1 \text { if there is a shareholder with more than } 25 \% \text { of total ownership } \\
\text { but no shareholder with more than } 50 \% \text { of total ownership in } 2009,{ }^{\mathrm{c}} \text { and } 0 \text { otherwise }\end{array}$ & $\begin{array}{l}\text { Excluded from } \\
\text { regressions to } \\
\text { avoid perfect } \\
\text { collinearity }\end{array}$ \\
\hline IND3 & $\begin{array}{l}\text { Dummy variable: } 1 \text { if there is a shareholder with more than } 50 \% \text { of total ownership } \\
\text { in } 2009,{ }^{\mathrm{c}} \text { and } 0 \text { otherwise }\end{array}$ & Negative \\
\hline Profitability & $\begin{array}{l}\text { Net income of bank } i \text { in year } t \text { plus the loan loss provision of bank } i \text { in year } t \text { divided } \\
\text { by the total assets of bank } i \text { in year } t \text {. I prefer using ROA over return on equity } \\
\text { because it does not take into account the effect of leverage on profitability and risk. }\end{array}$ & Positive \\
\hline Loan Growth & Log of loans of bank $i$ in period $t$ minus $\log$ of loans of bank $i$ in period $t-1$ & Negative \\
\hline Size & Log of assets of bank $i$ in period $t$ & Positive \\
\hline Earned Equity & $\begin{array}{l}\text { Retained earnings of bank } i \text { in period } t \text { divided by the total equity of bank } i \text { in period } \\
t\end{array}$ & Positive \\
\hline$I P O$ & Dummy variable: 1 if bank $i$ went public in period $t$, and 0 otherwise & Positive \\
\hline U.S. & Dummy variable: 1 if bank $i$ has its headquarters in the U.S. and 0 otherwise & Positive \\
\hline
\end{tabular}


${ }^{a}$ The IO conflict should be stronger in cases where the shareholding base is more dispersed. The number of recorded shareholders and listing on a stock exchange should be positively related to shareholding dispersion, and should therefore lead to higher payout ratios. However, quotation on a stock exchange can act as a monitoring device for shareholders (Easterbrook, 1984). Thus, the expected coefficient of Listed Bank may be positive or negative (or insignificant). The dummy variables IND1, IND2, and IND3 are independence indicators. Because Listed Bank, Recorded Shareholders, and the independence indicators are highly correlated, they are included one at a time in my multivariate analysis.

${ }^{\mathrm{b}}$ To allow for earnings management, I calculate the ROA as the sum of net income and loan loss provisions, divided by total assets. However, the pairwise correlation between the unadjusted ROA and the adjusted ROA is 0.8178 , (significant at the $1 \%$ ), and therefore the results are likely to hold, irrespective of the proxy chosen.

${ }^{\mathrm{c}}$ Bankscope provides data for these variables only as of the last accounting year available. However, because these data tend to be sticky, it is unlikely that this has affected my results. 
Table 2.Construction of the sample: 741 U.S. and EU banks, sample period 2000-2007, annual data. Search criterion

Number of banks

Panel A: All banks.

\begin{tabular}{llr}
\hline Step 1 & $\begin{array}{l}\text { Geographic: U.S. and EU (27), } \\
\text { for the period 1999-2008 }\end{array}$ & 25,104 \\
\hline Step 2 & $\begin{array}{l}\text { Specialisation: BHCs, } \\
\text { commercial banks, cooperative } \\
\text { banks, savings banks }\end{array}$ & 22,585 \\
\hline Step 3 & $\begin{array}{l}\text { Consolidated accounts: C1 and } \\
\text { C2 in Bankscope }\end{array}$ & 3,974 \\
\hline Step 4 & $\begin{array}{l}\text { Information availability: listing } \\
\text { on a stock exchange (listed, } \\
\text { unlisted, or delisted) }\end{array}$ & 3,968 \\
\hline Step 5 & $\begin{array}{l}\text { Information availability: } \\
\text { dividends for year } t \text { and for year } \\
t-1\end{array}$ \\
\hline
\end{tabular}

Panel B: Sub-sample of 166 listed banks.

\begin{tabular}{llr}
\hline Step 7 & $\begin{array}{l}\text { Information availability on } \\
\text { Thomson Analytics }\end{array}$ & 187 \\
\hline Step 8 & $\begin{array}{l}\text { Information availability: } \\
\text { dividends for year } t \text { and for year } \\
t-1\end{array}$ & 184 \\
\hline Step 9 & $\begin{array}{l}\text { Information availability: other } \\
\text { explanatory variables }\end{array}$ & 166 \\
\hline
\end{tabular}


Table 3. Descriptive statistics: 741 U.S. and EU banks, sample period 2000-2007, annual data.

\begin{tabular}{|c|c|c|c|c|c|c|}
\hline & & U.S. & $\mathbf{E U}$ & Listed & Unlisted & All \\
\hline \multirow{5}{*}{$\begin{array}{r}\text { Sample } \\
\text { composition }\end{array}$} & All Banks & 435 & 306 & $396^{\mathrm{a}}$ & 352 & 741 \\
\hline & BHCs & 354 & 29 & 287 & 99 & 383 \\
\hline & Commercial & 78 & 200 & 89 & 193 & 278 \\
\hline & Cooperative & 1 & 44 & 16 & 29 & 45 \\
\hline & Savings & 2 & 33 & 4 & 31 & 35 \\
\hline \multirow{6}{*}{$D P$} & Obs & 2234 & 679 & 1705 & 1208 & 2913 \\
\hline & Mean & 0.415 & 0.382 & 0.406 & 0.408 & 0.407 \\
\hline & SD & 0.810 & 0.397 & 0.555 & 0.932 & 0.735 \\
\hline & $\mathrm{p} 50$ & 0.339 & 0.306 & 0.356 & 0.268 & 0.333 \\
\hline & p1 & 0.000 & 0.000 & 0.000 & 0.000 & 0.000 \\
\hline & p99 & 2.323 & 1.886 & 1.669 & 2.564 & 2.106 \\
\hline \multirow{6}{*}{$\operatorname{LnZ}$} & Obs & 2234 & 679 & 1705 & 1208 & 2913 \\
\hline & Mean & $4.328^{* * *}$ & 3.786 & $4.305^{* * *}$ & 4.056 & 4.201 \\
\hline & SD & 0.934 & 1.078 & 0.943 & 1.050 & 0.996 \\
\hline & p50 & 4.323 & 3.794 & 4.309 & 4.121 & 4.216 \\
\hline & $\mathrm{p} 1$ & 1.675 & 1.338 & 1.992 & 1.329 & 1.539 \\
\hline & p99 & 6.596 & 6.641 & 6.587 & 6.627 & 6.596 \\
\hline \multirow{6}{*}{ Capital Ratio } & Obs & 2234 & 679 & 1705 & 1208 & 2913 \\
\hline & Mean & $0.098^{* * *}$ & 0.077 & $0.091^{\text {** }}$ & 0.095 & 0.093 \\
\hline & SD & 0.039 & 0.051 & 0.037 & 0.050 & 0.043 \\
\hline & $\mathrm{p} 50$ & 0.091 & 0.068 & 0.089 & 0.086 & 0.088 \\
\hline & p1 & 0.054 & 0.017 & 0.028 & 0.022 & 0.026 \\
\hline & p99 & 0.262 & 0.237 & 0.179 & 0.315 & 0.255 \\
\hline \multirow{6}{*}{$S D R O A$} & Obs & 2234 & 679 & 1705 & 1208 & 2913 \\
\hline & Mean & $0.003^{* *}$ & 0.004 & $0.002^{* * * *}$ & 0.004 & 0.003 \\
\hline & SD & 0.007 & 0.016 & 0.006 & 0.014 & 0.010 \\
\hline & $\mathrm{p} 50$ & 0.001 & 0.002 & 0.001 & 0.002 & 0.001 \\
\hline & p1 & 0.000 & 0.000 & 0.000 & 0.000 & 0.000 \\
\hline & p99 & 0.022 & 0.036 & 0.016 & 0.028 & 0.023 \\
\hline \multirow{6}{*}{ Profitability } & Obs & 2234 & 679 & 1705 & 1208 & 2913 \\
\hline & Mean & $0.014^{* * *}$ & 0.012 & $0.013^{*}$ & 0.014 & 0.014 \\
\hline & SD & 0.012 & 0.011 & 0.008 & 0.015 & 0.011 \\
\hline & p50 & 0.013 & 0.011 & 0.012 & 0.012 & 0.012 \\
\hline & p1 & 0.002 & -0.002 & 0.003 & -0.003 & 0.001 \\
\hline & p99 & 0.051 & 0.047 & 0.036 & 0.059 & 0.051 \\
\hline \multirow{6}{*}{ Close } & Obs & 2234 & 679 & 1705 & 1208 & 2913 \\
\hline & Mean & $0.016^{* * *}$ & 0.090 & 0.031 & 0.036 & 0.033 \\
\hline & SD & 0.124 & 0.286 & 0.174 & 0.185 & 0.179 \\
\hline & p50 & 0 & 0 & 0 & 0 & 0 \\
\hline & p1 & 0 & 0 & 0 & 0 & 0 \\
\hline & p99 & 1 & 1 & 1 & 1 & 1 \\
\hline \multirow{6}{*}{ High Charter } & Obs & 2234 & 679 & 1705 & 1208 & 2913 \\
\hline & Mean & $0.623^{* * *}$ & 0.178 & $0.554^{* * *}$ & 0.469 & 0.519 \\
\hline & SD & 0.485 & 0.383 & 0.497 & 0.499 & 0.500 \\
\hline & p50 & 1 & 0 & 1 & 0 & 1 \\
\hline & p1 & 0 & 0 & 0 & 0 & 0 \\
\hline & p99 & 1 & 1 & 1 & 1 & 1 \\
\hline
\end{tabular}

All the statistics are shown for banks for which $D P$ and the explanatory variables (including the first lag of the payout ratio, $D P(-1)$ ) are available. Observations for which the payout ratio is negative are dropped. Table 1 reports a detailed description of each variable in the regressions.

${ }^{a}$ Seven banks went public or were delisted during the sample period (three BHCs and four commercial banks). For this reason, they appear as both listed and unlisted, respectively, causing the sum of the banks in the columns Listed and Unlisted to be 748 instead of 741.

The superscripts $* * *, * *$, and * indicate the means of the two sub-samples (U.S. and EU, or Listed and Unlisted) are significantly different at the $1 \%, 5 \%$, and $10 \%$ levels, respectively, according to a two-sample t-test with unequal variances. 
Table 4. Descriptive statistics: Sub-sample of 166 US and EU listed banks, sample period 2000-2007, annual data.

\begin{tabular}{|c|c|c|c|c|}
\hline & & U.S. & $\mathbf{E U}$ & All \\
\hline \multirow{5}{*}{ Sample composition } & All Banks & 106 & 60 & 166 \\
\hline & BHCs & 105 & 13 & 118 \\
\hline & Commercial & 1 & 37 & 38 \\
\hline & Cooperative & 0 & 7 & 7 \\
\hline & Savings & 0 & 3 & 3 \\
\hline \multirow{6}{*}{$D Y$} & Obs & 400 & 132 & 532 \\
\hline & Mean & $0.027 * * *$ & 0.054 & 0.034 \\
\hline & SD & 0.018 & 0.094 & 0.051 \\
\hline & p50 & 0.025 & 0.031 & 0.026 \\
\hline & p1 & 0.000 & 0.000 & 0.000 \\
\hline & P99 & 0.082 & 0.550 & 0.190 \\
\hline \multirow{6}{*}{ Nä̈ve $D D$} & Obs & 400 & 132 & 532 \\
\hline & Mean & $0.387 * * *$ & 0.278 & 0.360 \\
\hline & SD & 0.409 & 0.397 & 0.408 \\
\hline & $\mathrm{p} 50$ & 0.285 & 0.120 & 0.251 \\
\hline & $\mathrm{p} 1$ & 0.000 & 0.000 & 0.000 \\
\hline & P99 & 1.679 & 1.839 & 1.690 \\
\hline \multirow{6}{*}{$E D F$} & Obs & 400 & 132 & 532 \\
\hline & Mean & $0.363 * * *$ & 0.403 & 0.373 \\
\hline & SD & 0.129 & 0.125 & 0.129 \\
\hline & $\mathrm{p} 50$ & 0.388 & 0.452 & 0.401 \\
\hline & p1 & 0.047 & 0.033 & 0.045 \\
\hline & P99 & 0.500 & 0.500 & 0.500 \\
\hline \multirow{6}{*}{ Close } & Obs & 400 & 132 & 532 \\
\hline & Mean & $0.003 * * *$ & 0.136 & 0.036 \\
\hline & SD & 0.050 & 0.344 & 0.186 \\
\hline & p50 & 0.000 & 0.000 & 0.000 \\
\hline & $\mathrm{p} 1$ & 0.000 & 0.000 & 0.000 \\
\hline & P99 & 1.000 & 1.000 & 1.000 \\
\hline \multirow{6}{*}{ High Charter } & Obs & 400 & 132 & 532 \\
\hline & Mean & 0.570 & 0.606 & 0.579 \\
\hline & SD & 0.496 & 0.490 & 0.494 \\
\hline & $\mathrm{p} 50$ & 1 & 1 & 1 \\
\hline & p1 & 0 & 0 & 0 \\
\hline & P99 & 1 & 1 & 1 \\
\hline
\end{tabular}


Table 5. Regression results for the dividend payout ratio (DP): 741 U.S. and EU banks, sample period 2000-2007.

\begin{tabular}{|c|c|c|c|c|c|c|c|c|}
\hline & (1) & (2) & (3) & (4) & (1) & (2) & (3) & (4) \\
\hline & \multicolumn{4}{|c|}{ Whole sample } & \multicolumn{4}{|c|}{ BHC and commercial banks } \\
\hline$D P(-1)$ & $\begin{array}{c}0.304 * * * \\
(0.109)\end{array}$ & $\begin{array}{c}0.300^{* * * *} \\
(0.111)\end{array}$ & $\begin{array}{c}0.283 * * \\
(0.122)\end{array}$ & $\begin{array}{c}0.276 * * \\
(0.125)\end{array}$ & $\begin{array}{c}0.303 * * * \\
(0.1102)\end{array}$ & $\begin{array}{c}0.300 * * * \\
(0.113)\end{array}$ & $\begin{array}{c}0.277 * * \\
(0.124)\end{array}$ & $\begin{array}{c}0.272 * * \\
(0.128)\end{array}$ \\
\hline $\operatorname{LnZ}$ & $\begin{array}{c}-0.081 * * * * \\
(0.030)\end{array}$ & $\begin{array}{c}-0.084 * * * \\
(0.030)\end{array}$ & $\begin{array}{c}-0.134 * * \\
(0.058)\end{array}$ & $\begin{array}{c}-0.142 * * \\
(0.060)\end{array}$ & $\begin{array}{c}-0.084 * * * \\
(0.031)\end{array}$ & $\begin{array}{c}-0.084 * * * \\
(0.031)\end{array}$ & $\begin{array}{c}-0.152 * * \\
(0.063)\end{array}$ & $\begin{array}{c}-0.156 * * \\
(0.063)\end{array}$ \\
\hline Close $\mathrm{x} \operatorname{LnZ}$ & & $\begin{array}{c}0.114 * * * \\
(0.043)\end{array}$ & & $\begin{array}{l}0.151 * * \\
(0.059)\end{array}$ & & $\begin{array}{c}0.113 * * \\
(0.048)\end{array}$ & & $\begin{array}{c}0.156 * * \\
(0.062)\end{array}$ \\
\hline $\begin{array}{l}\text { Controls } \\
\text { Year effects }\end{array}$ & $\begin{array}{l}\text { Yes } \\
\text { Yes }\end{array}$ & $\begin{array}{l}\text { Yes } \\
\text { Yes }\end{array}$ & $\begin{array}{l}\text { Yes } \\
\text { Yes }\end{array}$ & $\begin{array}{l}\text { Yes } \\
\text { Yes }\end{array}$ & $\begin{array}{l}\text { Yes } \\
\text { Yes }\end{array}$ & $\begin{array}{l}\text { Yes } \\
\text { Yes }\end{array}$ & $\begin{array}{l}\text { Yes } \\
\text { Yes }\end{array}$ & $\begin{array}{l}\text { Yes } \\
\text { Yes }\end{array}$ \\
\hline $\begin{array}{l}\text { Observ.s } \\
\text { Banks }\end{array}$ & $\begin{array}{c}2913 \\
741\end{array}$ & $\begin{array}{c}2913 \\
741\end{array}$ & $\begin{array}{c}2913 \\
741\end{array}$ & $\begin{array}{c}2913 \\
741\end{array}$ & $\begin{array}{c}2,749 \\
661\end{array}$ & $\begin{array}{c}2,749 \\
661\end{array}$ & $\begin{array}{c}2,749 \\
661\end{array}$ & $\begin{array}{c}2,749 \\
661\end{array}$ \\
\hline Wald $\chi^{2}$ & 74.66 & 93.49 & 84.31 & 102.1 & 78.00 & 98.17 & 92.09 & 109.6 \\
\hline Hansen & 14.98 & 14.70 & 16.24 & 15.72 & 14.42 & 14.20 & 15.03 & 14.57 \\
\hline $\begin{array}{l}\text { Hansen } \\
\text { p-value }\end{array}$ & 0.243 & 0.259 & 0.180 & 0.204 & 0.275 & 0.288 & 0.240 & 0.266 \\
\hline
\end{tabular}

Table 5 reports the results for equation (1), where the dependent variable is the ratio of dividends to net income $(D P)$. Standard errors are reported in parentheses. The variable $\operatorname{LnZ}$ (natural logarithm of the Z-score) is considered to be endogenous. In specifications 2 and 4, Close is a dummy variable equal to one if Tier $1<6 \%$ or TCR $<10 \%$, and zero otherwise. In specifications 3 and 4 , High Charter is a dummy variable equal to one if the ratio of customer deposits to total assets is larger than the sample median, and zero otherwise. Controls include the variables Loan Growth, Size, Earned Equity, IPO, Listed Bank, U.S., and year dummies. Table 1 reports a detailed description of each variable in the regressions. Notations $\mathrm{m} 1$ and $\mathrm{m} 2$ refer to tests for the absence of first- and second-order autocorrelation in the first-differenced residuals, respectively. Under the null hypothesis, $\mathrm{m} 1$ and $\mathrm{m} 2$ are asymptotically distributed as standard normal variables with mean zero and variance one. The statistic $\mathrm{m} 2$ being significantly different from zero is not consistent with the assumption of no serial correlation across disturbances (the assumptions of the GMM-SYS model are invalid). Hansen refers to the test statistic for over-identifying restrictions, distributed asymptotically as $\chi^{2}$ (df) when the null hypothesis of exogeneity of the instruments is satisfied. All GMM-SYS regressions are estimated using a two-step approach and standard errors are adjusted using Windmeijer (2005) small-sample variance correction (Roodman, 2006). The superscripts ***, **, and * denote significance at the $1 \%, 5 \%$, and $10 \%$ level, respectively. 
Table 6. Regression results for the dividend payout ratio $(D P)$ - English Origin and English Origin with only BHC and Commercial banks. Sample period 2000-2007.

\begin{tabular}{|c|c|c|c|c|c|c|c|c|}
\hline & (1) & (2) & (3) & (4) & (1) & (2) & (3) & (4) \\
\hline & \multicolumn{4}{|c|}{ English Origin (Whole sample) } & \multicolumn{4}{|c|}{ English Origin (BHC and commercial banks) } \\
\hline$D P(-1)$ & $\begin{array}{c}0.401 * * * \\
(0.093)\end{array}$ & $\begin{array}{c}0.403 * * * \\
(0.093)\end{array}$ & $\begin{array}{c}0.358^{* * * *} \\
(0.117)\end{array}$ & $\begin{array}{c}0.359 * * * \\
(0.117)\end{array}$ & $\begin{array}{c}0.397 * * * \\
(0.093)\end{array}$ & $\begin{array}{c}0.399 * * * \\
(0.093)\end{array}$ & $\begin{array}{c}0.350 * * * \\
(0.116)\end{array}$ & $\begin{array}{c}0.351^{* * * *} \\
(0.116)\end{array}$ \\
\hline $\operatorname{Ln} Z$ & $\begin{array}{c}-0.098 * * * \\
(0.029)\end{array}$ & $\begin{array}{c}-0.098 * * * \\
(0.029)\end{array}$ & $\begin{array}{c}-0.194 * * * \\
(0.057)\end{array}$ & $\begin{array}{c}-0.193 * * * \\
(0.056)\end{array}$ & $\begin{array}{c}-0.099 * * * \\
(0.029)\end{array}$ & $\begin{array}{c}-0.100 * * * \\
(0.029)\end{array}$ & $\begin{array}{c}-0.199 * * * \\
(0.057)\end{array}$ & $\begin{array}{c}-0.197 * * * \\
(0.057)\end{array}$ \\
\hline Close & & $\begin{array}{c}-0.562 * * * \\
(0.148)\end{array}$ & & $\begin{array}{c}-0.809 * * * \\
(0.222)\end{array}$ & & $\begin{array}{c}-0.561 * * * \\
(0.148)\end{array}$ & & $\begin{array}{c}-0.819 * * * \\
(0.222)\end{array}$ \\
\hline Close $\mathrm{x} \operatorname{LnZ}$ & & $\begin{array}{c}0.094 * * * \\
(0.032)\end{array}$ & & $\begin{array}{c}0.153 * * * \\
(0.050)\end{array}$ & & $\begin{array}{c}0.094 * * * \\
(0.032)\end{array}$ & & $\begin{array}{c}0.155^{* * * *} \\
(0.050)\end{array}$ \\
\hline \multicolumn{2}{|l|}{ High Charter } & & $\begin{array}{c}-0.888 * * * \\
(0.254)\end{array}$ & $\begin{array}{c}-0.874 * * * \\
(0.249)\end{array}$ & & & $\begin{array}{c}-0.913 * * * \\
(0.256)\end{array}$ & $\begin{array}{c}-0.899 * * * \\
(0.251)\end{array}$ \\
\hline \multicolumn{2}{|c|}{ High Charter $\mathrm{x}$ LnZ } & & $\begin{array}{c}0.191^{* * *} \\
(0.058)\end{array}$ & $\begin{array}{c}0.188^{* * * *} \\
(0.057)\end{array}$ & & & $\begin{array}{c}0.196 * * * \\
(0.058)\end{array}$ & $\begin{array}{c}0.194 * * * \\
(0.057)\end{array}$ \\
\hline Controls & Yes & Yes & Yes & Yes & Yes & Yes & Yes & Yes \\
\hline Year effects & Yes & Yes & Yes & Yes & Yes & Yes & Yes & Yes \\
\hline Observ.s & 2,287 & 2,287 & 2,287 & 2,287 & 2,272 & 2,272 & 2,272 & 2,272 \\
\hline Banks & 464 & 464 & 464 & 464 & 460 & 460 & 460 & 460 \\
\hline Wald $\chi^{2}$ & 104.8 & 257.2 & 109.0 & 246.4 & 104.9 & 252.9 & 108.3 & 245.3 \\
\hline Hansen & 9.283 & 9.409 & 9.162 & 9.205 & 9.000 & 9.122 & 8.766 & 8.806 \\
\hline $\begin{array}{l}\text { Hansen } \\
\text { p-value }\end{array}$ & 0.679 & 0.668 & 0.689 & 0.685 & 0.703 & 0.692 & 0.723 & 0.719 \\
\hline $\begin{array}{l}\text { Number of } \\
\text { instruments }\end{array}$ & 28 & 30 & 30 & 32 & 28 & 30 & 30 & 32 \\
\hline$m 1$ & -1.872 & -1.875 & -1.808 & -1.813 & -1.867 & -1.870 & -1.799 & -1.804 \\
\hline$m 2$ & 0.998 & 1.006 & 1.075 & 1.084 & 0.98 & 0.997 & 1.056 & 1.067 \\
\hline m1 p-value & 0.061 & 0.061 & 0.071 & 0.070 & 0.062 & 0.061 & 0.072 & 0.071 \\
\hline m2p-value & 0.318 & 0.314 & 0.282 & 0.278 & 0.323 & 0.319 & 0.291 & 0.286 \\
\hline \multicolumn{9}{|c|}{$\begin{array}{l}\text { Table } 6 \text { reports the results for equation (1), where the dependent variable is the ratio of dividends to net income (DP). Standard errors } \\
\text { are reported in parentheses. The variable LnZ (natural logarithm of the Z-score) is considered to be endogenous. In specifications } 2 \\
\text { and } 4 \text {, Close is a dummy variable equal to one if Tier } 1<6 \% \text { or TCR }<10 \% \text {, and zero otherwise. In specifications } 3 \text { and } 4 \text {, High } \\
\text { Charter is a dummy variable equal to one if the ratio of customer deposits to total assets is larger than the sample median, and zero } \\
\text { otherwise. Controls include the variables Loan Growth, Size, Earned Equity, IPO, Listed Bank, U.S., and year dummies. Table } 1 \\
\text { reports a detailed description of each variable in the regressions. Notations } \mathrm{m} 1 \text { and } \mathrm{m} 2 \text { refer to tests for the absence of first- and } \\
\text { second-order autocorrelation in the first-differenced residuals, respectively. Under the null hypothesis, m1 and m2 are asymptotically } \\
\text { distributed as standard normal variables with mean zero and variance one. The statistic m2 being significantly different from zero is } \\
\text { not consistent with the assumption of no serial correlation across disturbances (the assumptions of the GMM-SYS model are invalid). } \\
\text { Hansen refers to the test statistic for over-identifying restrictions, distributed asymptotically as } \chi^{2}(\mathrm{df}) \text { when the null hypothesis of } \\
\text { exogeneity of the instruments is satisfied. All GMM-SYS regressions are estimated using a two-step approach and standard errors are } \\
\text { adjusted using Windmeijer (2005) small-sample variance correction (Roodman, 2006). The superscripts } * * *, * * \text { and } * \text { denote } \\
\text { significance at the } 1 \%, 5 \% \text {, and } 10 \% \text { level, respectively. }\end{array}$} \\
\hline
\end{tabular}


Table 7. Regression results for the dividend payout ratio $(D P)$ - Effects of PCA: 741 U.S. and EU banks, sample period 2000-2007.

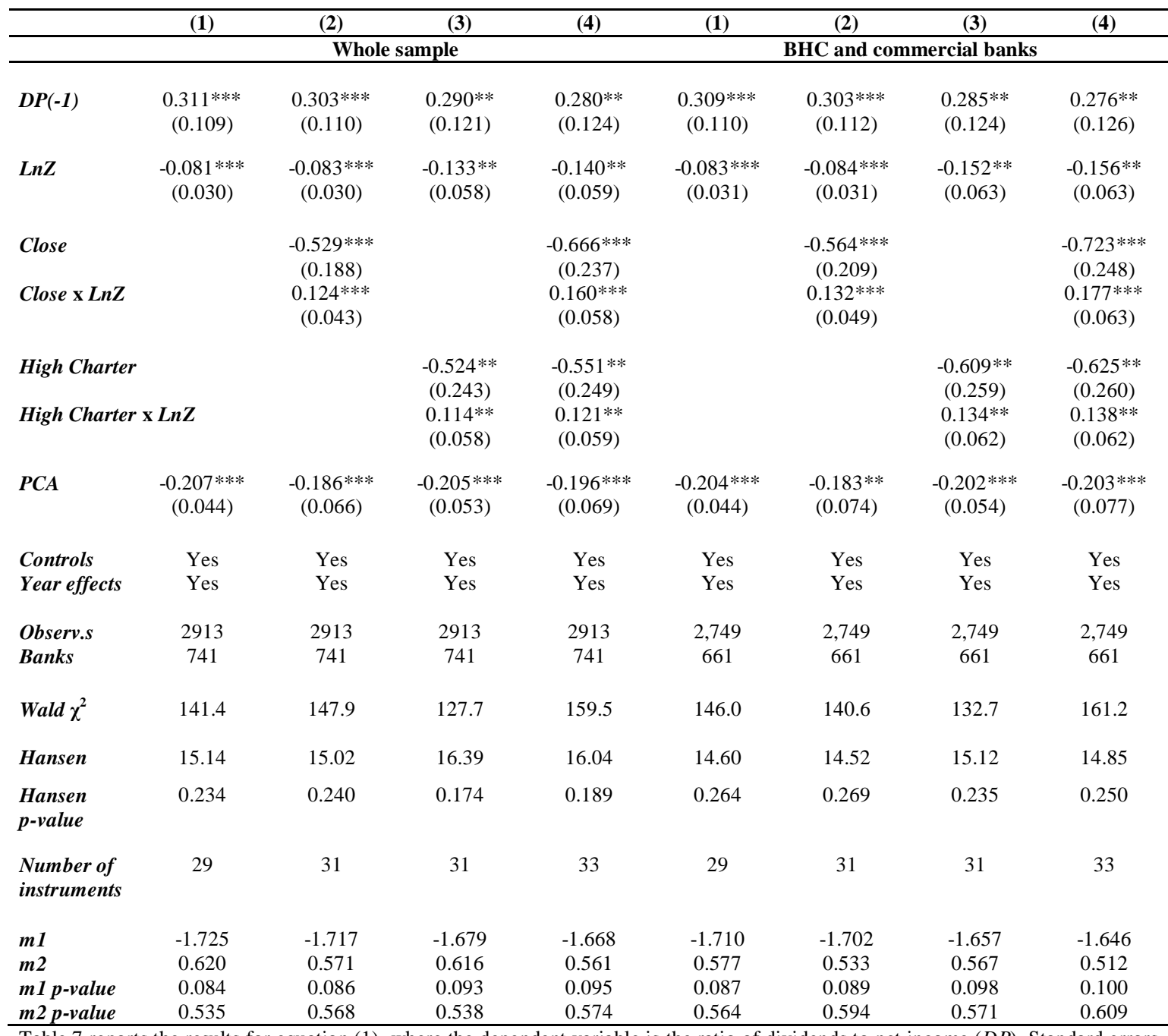

Table 7 reports the results for equation (1), where the dependent variable is the ratio of dividends to net income (DP). Standard errors are reported in parentheses. The variable $\operatorname{LnZ}$ (natural logarithm of the Z-score) is considered to be endogenous. In specifications 2 and 4, Close is a dummy variable equal to one if Tier $1<6 \%$ or TCR $<10 \%$, and zero otherwise. In specifications 3 and 4 , High Charter is a dummy variable equal to one if the ratio of customer deposits to total assets is larger than the sample median, and zero otherwise. PCA is a dummy equal to one if Close $=1$ and U.S.=1, and zero otherwise. Controls include the variables Loan Growth, Size, Earned Equity, IPO, Listed Bank, U.S., and year dummies. Table 1 reports a detailed description of each variable in the regressions. Notations $\mathrm{m} 1$ and $\mathrm{m} 2$ refer to tests for the absence of first- and second-order autocorrelation in the first-differenced residuals, respectively. Under the null hypothesis, $\mathrm{m} 1$ and $\mathrm{m} 2$ are asymptotically distributed as standard normal variables with mean zero and variance one. The statistic $\mathrm{m} 2$ being significantly different from zero is not consistent with the assumption of no serial correlation across disturbances (the assumptions of the GMM-SYS model are invalid). Hansen refers to the test statistic for over-identifying restrictions, distributed asymptotically as $\chi^{2}(\mathrm{df})$ when the null hypothesis of exogeneity of the instruments is satisfied. All GMM-SYS regressions are estimated using a two-step approach and standard errors are adjusted using Windmeijer (2005) small-sample variance correction (Roodman, 2006). The superscripts ***, **, and * denote significance at the 1\%, 5\%, and $10 \%$ level, respectively. 
Table 8. Regression results for the dividends to market value of equity ratio (DY) using BS (2008) 'naïve' distance to default measure: 166 listed banks, sample period 2000-2007.

\begin{tabular}{|c|c|c|c|c|c|c|c|c|}
\hline & (1) & $(2)$ & (3) & (4) & (1) & (2) & (3) & (4) \\
\hline & \multicolumn{4}{|c|}{ Whole sample } & \multicolumn{4}{|c|}{ BHC and commercial banks } \\
\hline$D Y(-1)$ & $\begin{array}{c}0.445^{* * * *} \\
(0.140)\end{array}$ & $\begin{array}{c}0.438 * * * \\
(0.139)\end{array}$ & $\begin{array}{c}0.332 * * * \\
(0.116)\end{array}$ & $\begin{array}{c}0.333 * * * \\
(0.117)\end{array}$ & $\begin{array}{c}0.512 * * \\
(0.210)\end{array}$ & $\begin{array}{c}0.506 * * \\
(0.211)\end{array}$ & $\begin{array}{c}0.422 * * \\
(0.185)\end{array}$ & $\begin{array}{c}0.423 * * \\
(0.185)\end{array}$ \\
\hline Nä̈ve DD & $\begin{array}{c}-0.008 * * * \\
(0.003)\end{array}$ & $\begin{array}{c}-0.008 * * \\
(0.003)\end{array}$ & $\begin{array}{c}-0.047 * * * \\
(0.014)\end{array}$ & $\begin{array}{c}-0.045^{* * *} * \\
(0.014)\end{array}$ & $\begin{array}{c}-0.008 * * * \\
(0.002)\end{array}$ & $\begin{array}{c}-0.008 * * * \\
(0.002)\end{array}$ & $\begin{array}{c}-0.033 * * * \\
(0.011)\end{array}$ & $\begin{array}{c}-0.033 * * * \\
(0.011)\end{array}$ \\
\hline Close $\mathbf{x}$ Nä̈ve & & $\begin{array}{c}0.007 \\
(0.017)\end{array}$ & & $\begin{array}{c}0.004 \\
(0.024)\end{array}$ & & $\begin{array}{c}0.007 \\
(0.027)\end{array}$ & & $\begin{array}{c}0.002 \\
(0.031)\end{array}$ \\
\hline High Charter & & & $\begin{array}{c}-0.017 * * * \\
(0.005)\end{array}$ & $\begin{array}{c}-0.016^{* * * *} \\
(0.003)\end{array}$ & & & $\begin{array}{c}-0.013 * * * \\
(0.003)\end{array}$ & $\begin{array}{c}-0.013 * * * \\
(0.003)\end{array}$ \\
\hline Controls & Yes & Yes & Yes & Yes & Yes & Yes & Yes & Yes \\
\hline Year effects & Yes & Yes & Yes & Yes & Yes & Yes & Yes & Yes \\
\hline Observ.s & 532 & 532 & 532 & 532 & 511 & 511 & 511 & 511 \\
\hline Banks & 166 & 166 & 166 & 166 & 156 & 156 & 156 & 156 \\
\hline Wald $\chi^{2}$ & 121.8 & 119.2 & 148.5 & 144.4 & 145.2 & 144.6 & 193.7 & 194.3 \\
\hline Hansen & 8.114 & 7.686 & 7.492 & 7.086 & 7.820 & 7.747 & 6.409 & 6.409 \\
\hline $\begin{array}{l}\text { Hansen } \\
\text { p-value }\end{array}$ & 0.618 & 0.659 & 0.678 & 0.717 & 0.646 & 0.653 & 0.780 & 0.780 \\
\hline
\end{tabular}

Table 8 reports the results for equation (1), where the dependent variable is the ratio of dividends to market value of equity $(D Y)$. Standard errors are reported in parentheses. The variable Nä̈ve DD is considered to be endogenous. In specifications 2 and 4 , Close is a dummy variable equal to one if Tier $1<6 \%$ or TCR $<10 \%$, and zero otherwise. In specifications 3 and 4 , High Charter is a dummy variable equal to one if the market-to-book ratio is larger than the sample median, and zero otherwise. Notations $\mathrm{m} 1$ and $\mathrm{m} 2 \mathrm{refer}$ to tests for the absence of first- and second-order autocorrelation in the first-differenced residuals, respectively. Under the null hypothesis, $\mathrm{m} 1$ and $\mathrm{m} 2$ are asymptotically distributed as standard normal variables with mean zero and variance one. The statistic m2 being significantly different from zero is not consistent with the assumption of no serial correlation across disturbances (the assumptions of the GMM-SYS model are invalid). Hansen refers to the test statistic for over-identifying restrictions, distributed asymptotically as $\chi^{2}$ (df) when the null hypothesis of exogeneity of the instruments is satisfied. All GMM-SYS regressions are estimated using a two-step approach and standard errors are adjusted using Windmeijer (2005) small-sample variance correction (Roodman, 2006). The superscripts $* * *, * *$, and $*$ denote significance at the $1 \%, 5 \%$, and $10 \%$ level, respectively. 
Table 9. Regression results for the total payout ratio (TP) using BS (2008) 'naïve' distance to default measure: 166 listed banks, sample period 2000-2007.

\begin{tabular}{|c|c|c|c|c|c|c|c|c|}
\hline & (1) & (2) & (3) & (4) & (1) & $(2)$ & (3) & (4) \\
\hline & \multicolumn{4}{|c|}{ Whole sample } & \multicolumn{4}{|c|}{ BHC and commercial banks } \\
\hline$T P(-1)$ & $\begin{array}{c}0.567 * * * \\
(0.089)\end{array}$ & $\begin{array}{c}0.585 * * * \\
(0.092)\end{array}$ & $\begin{array}{c}0.556^{* * * *} \\
(0.086)\end{array}$ & $\begin{array}{c}0.572 * * * \\
(0.089)\end{array}$ & $\begin{array}{c}0.543 * * * \\
(0.092)\end{array}$ & $\begin{array}{c}0.556 * * * \\
(0.094)\end{array}$ & $\begin{array}{c}0.534 * * * \\
(0.088)\end{array}$ & $\begin{array}{c}0.544 * * * \\
(0.089)\end{array}$ \\
\hline Nä̈ve DD & $\begin{array}{c}-0.008 * * * \\
(0.002)\end{array}$ & $\begin{array}{c}-0.008 * * * \\
(0.002)\end{array}$ & $\begin{array}{c}-0.032 * * * \\
(0.011)\end{array}$ & $\begin{array}{c}-0.031 \text { *** } \\
(0.011)\end{array}$ & $\begin{array}{c}-0.008 * * * \\
(0.002)\end{array}$ & $\begin{array}{c}-0.008 * * * \\
(0.002)\end{array}$ & $\begin{array}{c}-0.034 * * * \\
(0.010)\end{array}$ & $\begin{array}{c}-0.034 * * * \\
(0.011)\end{array}$ \\
\hline Close $\mathbf{x}$ Nä̈ve & & $\begin{array}{c}0.004 \\
(0.017)\end{array}$ & & $\begin{array}{c}0.002 \\
(0.019)\end{array}$ & & $\begin{array}{c}0.004 \\
(0.024)\end{array}$ & & $\begin{array}{c}0.004 \\
(0.026)\end{array}$ \\
\hline High Charter & & & $\begin{array}{c}-0.011 * * * \\
(0.003)\end{array}$ & $\begin{array}{c}-0.010^{* * * *} \\
(0.003)\end{array}$ & & & $\begin{array}{c}-0.011 * * * \\
(0.003)\end{array}$ & $\begin{array}{c}-0.011 * * * \\
(0.003)\end{array}$ \\
\hline $\begin{array}{l}\text { Controls } \\
\text { Year effects }\end{array}$ & $\begin{array}{l}\text { Yes } \\
\text { Yes }\end{array}$ & $\begin{array}{l}\text { Yes } \\
\text { Yes }\end{array}$ & $\begin{array}{l}\text { Yes } \\
\text { Yes }\end{array}$ & $\begin{array}{l}\text { Yes } \\
\text { Yes }\end{array}$ & $\begin{array}{l}\text { Yes } \\
\text { Yes }\end{array}$ & $\begin{array}{l}\text { Yes } \\
\text { Yes }\end{array}$ & $\begin{array}{l}\text { Yes } \\
\text { Yes }\end{array}$ & $\begin{array}{l}\text { Yes } \\
\text { Yes }\end{array}$ \\
\hline $\begin{array}{l}\text { Observ.s } \\
\text { Banks }\end{array}$ & $\begin{array}{l}532 \\
166\end{array}$ & $\begin{array}{l}532 \\
166\end{array}$ & $\begin{array}{l}532 \\
166\end{array}$ & $\begin{array}{l}532 \\
166\end{array}$ & $\begin{array}{l}511 \\
156\end{array}$ & $\begin{array}{l}511 \\
156\end{array}$ & $\begin{array}{l}511 \\
156\end{array}$ & $\begin{array}{l}511 \\
156\end{array}$ \\
\hline Wald $\chi^{2}$ & 326.2 & 324.6 & 486.1 & 475.9 & 342.8 & 335.0 & 469.9 & 466.2 \\
\hline Hansen & 4.720 & 5.124 & 4.188 & 4.771 & 5.018 & 5.173 & 3.655 & 3.925 \\
\hline $\begin{array}{l}\text { Hansen } \\
\text { p-value }\end{array}$ & 0.944 & 0.925 & 0.964 & 0.942 & 0.930 & 0.922 & 0.979 & 0.972 \\
\hline \multicolumn{9}{|c|}{$\begin{array}{l}\text { Table } 9 \text { reports the results for equation (1), where the dependent variable is the total payout ratio }(T P) \text { : Dividends plus share } \\
\text { repurchases divided by the market value of equity. Standard errors are reported in parentheses. The variable Nä̈ve DD is considered to } \\
\text { be endogenous. In specifications } 2 \text { and } 4 \text {, Close is a dummy variable equal to one if Tier } 1<6 \% \text { or } T C R<10 \% \text {, and zero otherwise. In } \\
\text { specifications } 3 \text { and } 4 \text {, High Charter is a dummy variable equal to one if the market-to-book ratio is larger than the sample median, } \\
\text { and zero otherwise. Notations } \mathrm{m} 1 \text { and } \mathrm{m} 2 \text { refer to tests for the absence of first- and second-order autocorrelation in the first- } \\
\text { differenced residuals, respectively. Under the null hypothesis, } \mathrm{m} 1 \text { and } \mathrm{m} 2 \text { are asymptotically distributed as standard normal variables } \\
\text { with mean zero and variance one. The statistic } \mathrm{m} 2 \text { being significantly different from zero is not consistent with the assumption of no } \\
\text { serial correlation across disturbances (the assumptions of the GMM-SYS model are invalid). Hansen refers to the test statistic for } \\
\text { over-identifying restrictions, distributed asymptotically as } \chi^{2} \text { (df) when the null hypothesis of exogeneity of the instruments is satisfied. } \\
\text { All GMM-SYS regressions are estimated using a two-step approach and standard errors are adjusted using Windmeijer (2005) small- } \\
\text { sample variance correction (Roodman, 2006). The superscripts } * * *, * * \text {, and * denote significance at the } 1 \%, 5 \% \text {, and } 10 \% \text { level, } \\
\text { respectively. }\end{array}$} \\
\hline
\end{tabular}

